\title{
DRUG TESTING AND PUBLIC EMPLOYMENT: TOWARD A RATIONAL APPLICATION OF THE FOURTH AMENDMENT
}

\author{
JAMES FELMAN* \\ and Christopher J. Petrini $\dagger$
}

TABle of Contents

I. Introduction ..................................... 254

II. The Lines of Battle: Drug Use and Drug Testing in the Public

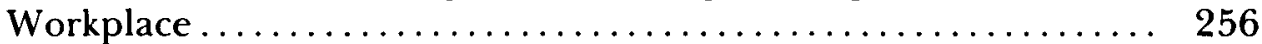

A. The Nature and Scope of the American Drug Problem ..... 256

1. How Many Drug Users Are There? ............. 256

2. At What Cost? ........................... 257

B. The Employers' Response: The Use and Variety of Drug

Testing............................. 259

1. The Increased Implementation of Drug Testing Programs 259

2. The Variety of Drug Testing Programs ........... 260

3. The Variety of Urine Tests .................. 261

C. A Critical Review of the Employers' Response: The Scientific

Limitations of Drug Testing Programs ............. 262

1. The Inherent Inaccuracy of EMIT Testing ......... 263

2. The Administrative Inaccuracy of Drug Testing ....... 264

3. Limitations on the Probative Value of Drug Testing .... 265

III. Drug Testing and the Fourth Amendment.............. 267

A. The Purpose and Scope of the Fourth Amendment ....... 267

B. The Threshold Issue: A Drug Test Is a Search .......... 269

C. The Individual Interests: The Intrusiveness of Drug Testing 270

D. The Governmental Interests .................... 273

1. The Safety/Efficiency Interest ............... 274

2. The Integrity Interest .................... 277

3. Policing Drug Use ..................... 279

E. Balancing the Competing Interests $\ldots \ldots \ldots \ldots \ldots \ldots \ldots \ldots 280$

F. Consent? .................................. 281

G. The Government as Employer .................. 282

H. Administrative Searches .................... 285

Copyright $@ 1988$ by Law and Contemporary Problems

Associate at the law firm of Winkles, Trombley, Kynes \& Markman, P.A., in Tampa, Florida.

+ Associate at the law firm of Sonnenschein Carlin Nath \& Rosenthal in Chicago, Illinois. 
I. The Supreme Court Docket: Von Raab and Burnley-Cert. Granted ...................................... 288

1. National Treasury Employees Union v. Von Raab .......... 288

2. Railway Labor Executives Association v. Burnley ............ 290

3. Von Raab and Burnley in the Supreme Court .......... 291

IV. Drug Testing and Procedural Due Process ................ 292

A. Protected Property Interests .................... 292

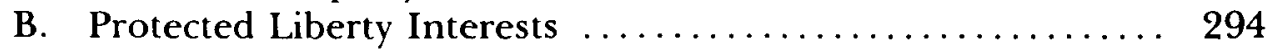

V. Conclusion ..................................... 296

The progress of science in furnishing the government with means of espionage is not likely to stop with wire tapping. Ways may some day be developed by which the government, without removing papers from secret drawers, can reproduce them in court, and by which it will be enabled to expose to a jury the most intimate occurrences of the home. Advances in the psychic and related sciences may bring means of exploring unexpressed beliefs, thoughts and emotions. ${ }^{1}$

\section{INTRODUCTION}

In the absence of legislative action, the fourth amendment to the Constitution provides the most important barrier to "the progress of science." Fourth amendment analysis inevitably involves a balancing of competing interests-the collective needs of the society must be tempered by the interests of individual human dignity and privacy. As these interests change and science progresses, new balances must be struck. The issue of drug testing in public employment presents a controversial example of such a new balance to be struck.

Significant societal interests are advanced in support of drug testing of public employees. Drug testing may increase employee safety and efficiency, ${ }^{2}$ enhance the perceived integrity of the particular public entity, ${ }^{3}$ as well as help reduce society's overall demand for illegal drugs. ${ }^{4}$ The individual interests implicated by drug testing are also formidable. Being told by the government to urinate into a jar brushes up against normal expectations of individual privacy. Moreover, the tests are sometimes inaccurate, falsely implicating innocent employees, ${ }^{5}$ and they reveal a broad array of private facts, such as pregnancy, medication for a psychological condition, and other similar information that is not of legitimate concern to employers. ${ }^{6}$

1. Olmstead v. United States, 277 U.S. 438, 474 (1928) (Brandeis, J., dissenting).

2. See infra notes $148-63$ and accompanying text.

3. See infra notes $164-67$ and accompanying text.

4. See infra notes 168-69 and accompanying text.

5. See infra notes 70-104 and accompanying text.

6. See infra notes 134-37 and accompanying text. 
This article focuses on the fourth amendment issues presented by the drug testing of public employees.7 This issue, in a nutshell, is whether an individual may be subjected to a highly intrusive bodily search in the absence of any individualized suspicion to ensure that she does not use drugs, whether at home or on the job. If upheld, drug testing will represent the first instance in the history of the fourth amendment in which a highly intrusive bodily search has been permitted without any measure of individualized suspicion. ${ }^{8}$ Such an erosion of the fourth amendment should not be allowed without a critical inquiry into the interests at stake, and the extent to which they are served by drug testing. The authors believe that this inquiry leads to the conclusion that testing public employees should be impermissible in the absence of individualized suspicion.

Even if the reader disagrees with the authors' conclusion, however, perhaps the more important point is that a critical examination of the competing interests involved should be used to draw the fourth amendment line between permissible and impermissible bodily searches in the absence of individualized suspicion. If this critical analysis is not adhered to, there may be no further fourth amendment lines left to draw, and the "progress of science" is surely not complete. ${ }^{9}$

Part II of the article presents a brief statistical overview of the nature and scope of illegal drug use in America. It discusses how many illegal drug users there are, who they are, and what costs they are estimated to impose upon

7. Unless otherwise stated, this article focuses solely upon drug testing of current public employees. Occasionally, however, reference will be made to the distinct issues raised by the drug testing of job applicants.

This article does not address employee drug testing in the private sector. Although the Constitution does not regulate the conduct of private entities unless they act in concert with or at the behest of a governmental entity, many of the arguments raised in this article against public sector testing apply with equal force to the private sector. Those arguments plainly suggest a pressing need for legislation to protect private sector employees from the degrading intrusion of urine testing. See Note, Drug Testing in the Workplace: A Legislative Proposal to Protect Privacy, 13 J. Lecis. 269 (1986) [hereinafter Legislative Proposal]. Several states and municipalities have already enacted or proposed legislation limiting the circumstances in which private employers may require employees to undergo drug testing. See McGuiness, Memorandum of the Equal Employment Advisory Council (Aug. 20, 1986); Palefsky, Corporate Vice Precedents: The California Constitution and San Francisco's Worker Privacy Ordinance, 11 Nova L. Rev. 669 (1987).

8. Although both searches without individualized suspicion and highly intrusive bodily searches have been allowed, they have never been permitted in conjunction. Cases upholding searches without individualized suspicion include United States v. Martinez-Fuerte, 428 U.S. 543 (1976) (brief vehicle stops at fixed checkpoints to question occupants), and New York v. Burger, 107 S. Ct. 2636 (1987) (administrative search of business premises in closely regulated industry). Cases permitting highly intrusive bodily searches have generally required probable cause. See, e.g., Schmerber v. California, 384 U.S. 757 (1966) (compelled blood test permissible without warrant, but not without probable cause).

9. The issue, of course, is not whether drugs are harmful; they undoubtedly are. But the severity of the current drug problem must not be allowed to cloud the proper fourth amendment question: whether drug testing is a constitutionally permissible means of addressing the problem. As Justice Black warned nearly twenty years ago, "the narcotics traffic can too easily cause threats to our basic liberties by making attractive the adoption of constitutionally forbidden short cuts . . . " Turner v. United States, 396 U.S. 398, 427 (1970) (Black, J., dissenting). "Our Constitution was not written in the sands to be washed away by a wave of new judges blown in by each successive political wind." Id. at 426. 
American society. Part II also examines the prevalence of drug testing in the workplace, describes the forms of drug testing, and details the accuracy of drug testing. Part III of the article presents the major constitutional issue: whether drug testing of a public employee without any individualized suspicion of drug use is an unreasonable search and seizure in violation of the fourth amendment. This part of the article also discusses the first two drug testing cases to be heard by the United States Supreme Court, National Treasury Employees Union v. Von Raab, ${ }^{10}$ and Railway Labor Executives Association $v$. Burnley. ${ }^{11}$ The final part of the article discusses procedural due process issues raised by drug testing in the public sector.

\section{II}

\section{The Lines of Battle: Drug Use and Drug Testing in the Public WorkPLACE}

\section{A. The Nature and Scope of the American Drug Problem}

1. How Many Drug Users Are There? Unfortunately, there is a dearth of reliable scientific evidence detailing the extent of illegal drug use in America, although it is undoubtedly a serious problem. Illicit drug use per capita in this country is estimated to exceed that of any other industrialized nation. ${ }^{12}$ The permissiveness and experimentation of the 1960's included the use and acceptance of numerous illegal drugs. American illicit drug use increased throughout the 1960's and the 1970's, peaking by some estimates in 1979.13 Between 1979 and 1986 there was a statistically significant decline in illegal drug use. ${ }^{14}$ Accurate measurement of illicit drug use is difficult, however, because the relative popularity of illegal drugs fluctuates when inexpensive substitutes or new, more potent varieties of existing drugs reach the market. ${ }^{15}$ In 1982, narcotics officials estimated that 3 to 5 percent of the American work force used drugs regularly. ${ }^{16}$

10. 816 F.2d 170 (5th Cir. 1987), cerl. granted, 108 S. Ct. 1072 (1988).

11. 839 F.2d 575 (9th Cir.), cert. granted, 108 S. Ct. 2033 (1988).

12. Drug Abuse on the Job of Growing Concern, J. Commerce, Aug. 10, 1983, at 7A, col. 5. While director of the federal anti-drug South Florida Task Force, Vice President George Bush predicted that Americans would spend $\$ 100$ billion on illegal drugs in 1983, about $5 \%$ of the gross national product. Id.

13. Research Triangle Institute, Economic Costs to Society of Alcohol and Drug Abuse and Mental Illness: 1980 , at 6 (1984) [hereinafter R.T.I. Study].

14. Id.; see also Thomas, America's Crusade, Time, Sept. 15, 1986, at 62.

15. See Jekel \& Allen, Trends in Drug Abuse in the Mid-1980s, 60 Yale J. Biology \& MEd. 45, 45-46 (1987). Designer drugs are new, more powerful drugs created through the chemical modification of other drugs. Id. For instance, the opiate meperidine (Demerol) is often modified to create highly potent substances known as "designer heroins." Id. at 46. Designer drugs have a special advantage for users because they are not technically illegal until they are identified, evaluated, and added through administrative action to Schedule I or II under the Controlled Substances Act, 21 U.S.C. $\S 812$ (1972). Jekel \& Allen, supra, at 45-46.

16. Rohan, Pushers on the Payroll: A Nightmare for Management, Industry WeEk, Feb. 8, 1982, at 52. For statistical purposes, "regular use" is generally defined as use of an illegal drug during the month preceding a survey. Chicago Tribune, Nov. $7,1987, \S 1$, at 2, col. 2. According to the National Institute on Drug Abuse (NIDA), at least 62 million Americans twelve years or older have smoked marijuana at least once. Chicago Tribune, supra. In 1985, over 18 million Americans were regular 
To some extent, persons of all races, ethnicities, and socioeconomic backgrounds use illegal drugs. ${ }^{17}$ Ironically, however, studies identify the two extremes of poverty and affluence as characteristics often correlating with drug abuse. ${ }^{18}$ In a study examining whether particular ethnic and racial groups are more prone to alcohol or drug abuse, it was found that the percentage breakdown of ethnic and racial groups in drug or alcohol treatment programs merely reflected their percentage in the general population. ${ }^{19}$ In fact, prior use of alcohol or drugs was found to be a stronger predictor of abuse than race or ethnicity. ${ }^{20}$

\section{At What Cost? Employees who use illegal drugs regularly may use drugs} on the job or report to work under the influence of drugs. There is little evidence regarding the number of employees who may be impaired on the job, but those who use drugs on the job undoubtedly inflict upon employers increased costs from inefficiency, greater absenteeism, accidents, and insurance claims. The workplace costs of employee drug use are, however, difficult to estimate, in part because it is not always clear whether drug use by employees is a cause of inefficiency or merely a symptom of an already

users of marijuana, according to NIDA estimates. Id. One writer reported recently that the number of Americans who have tried cocaine now exceeds 22 million, of whom 4.3 million are current users. Thomas, supra note 14, at 62-63. A more recent study, however, indicates that cocaine use decreased by $20 \%$ in the United States in 1987 . The "significant decline" was attributed to changing attitudes among students and young adults rather than law enforcement efforts. Chicago Tribune, Jan. 14, 1988, $\$ 1$, at 1, cols. 2 \& 4 (citing UNiversity of Michigan INSTITUTE for Social Research, U.S. Dep't of Health \& Human Services, Drug Use Among american High School Students, College Students, and Other Young Adults (Jan. 1988)). To help put these statistics in perspective, it is important to keep in mind that the estimated number of drug users is based on the total population of the United States, which the Census Bureau estimated to be 243.4 million as of July, 1987. Chicago Tribune, Dec. $30,1987, \S 1$, at 4 , col. 1 .

Another journalist reported without citation that government calculations show regular drug use among $25 \%$ of the population. Castro, Battling the Enemy Within, Time, Mar. 17, 1986, at 53. The claim that one in four Americans uses illegal drugs once per month, however, suggests an epidemic of such titanic proportions as to strain the source's credibility severely. Such unsupported speculation contributes little to responsible debate on America's drug problem.

17. Castro, supra note 16, at 54. See The Executive Addict, ForTunE, June 24, 1985, at 24.

18. Jekel \& Allen, supra note $\mathbf{1 5}$, at $\mathbf{5 0}$. Jekel and Allen conclude that " $[\mathrm{t}] \mathrm{he}$ life style of poverty tends to provide a negative emotional state which often leads to drug use. At the other financial extreme, affluence makes drug addiction easier because of the availability of funds." Id. A Research Triangle Institute study suggests a closer tie between poverty and illegal drug use. In that study, "[i]t was found that persons who had ever used marijuana daily for a month or longer had household incomes 27.9 percent lower than persons with otherwise similar characteristics." R.T.I. STudy, supra note 13 , at 9 . Because of lack of data and the generally lower incidence of non-marijuana drug use, however, "statistical analysis of the impact of consumption of drugs other than marijuana yieided no significant results relating abuse of the drugs to household income." Id. at A-20.

19. Hubbard, Schlenger, Rachal, Bray, Craddock, Cavanaugh \& Ginzburg, Patterns of Alcohol and Drug Abuse in Drug Treatment Clients from Different Ethnic Backgrounds, 1987 ANNALS N.Y. ACAD. SCi. 60, 73.

20. Id. at 73-74. The authors conclude as follows:

In general, this analysis revealed that the ethnic differences in the patterns of alcohol consumption and alcohol-related problems for drug treatment clients are similar to those for the general population. However, what may be more revealing is the strong relationship between drug-use patterns with alcohol consumption and alcohol-related problems. This relationship Id. seems much stronger than the relationship with ethnicity. 
inefficient employee. ${ }^{21}$ The only study of the issue seems to have overlooked this difficulty, assuming all costs imposed by drug-using employees to have been caused by the drugs, not the employee. This study, by the Research Triangle Institute, estimated that employee drug use cost American industry $\$ 25.7$ billion in 1980, ${ }^{22}$ and that alcohol and drug use together cost American society as a whole an estimated $\$ 136.4$ billion. ${ }^{23}$ One drug consulting firm has reported that the average drug user is likely to be tardy three times as often as nonusers, request time off during work 2.2 times more often, and have 2.5 times as many absences of eight days or more. ${ }^{24}$ Other experts, however, dispute these statistics. ${ }^{25}$

Drug use on the job is also believed to increase workplace accidents. One writer suggests that drug users are three times as likely as nonusers to injure themselves or someone else on the job. ${ }^{26}$ Since 1975, investigators have attributed about fifty train accidents to workers impaired by drugs or alcohol. ${ }^{27}$ Medical and property insurance claims are estimated to be somewhat higher because of employee drug use. ${ }^{28}$ There may also be a connection between employee drug use and increased workplace theft and embezzlement. ${ }^{29}$ Authorities have uncovered several large-scale drug selling operations in employment settings. ${ }^{30}$

21. The U.S. Department of Health and Human Services reported to Congress in 1984 that the "difficult research task of identifying the extent to which drug and alcohol abuse affect specific indices of job performance for individual workers (abusers compared with nonabusers) has not been done." U.S. Dep't of Health \& Human Services, Pub. No. 851372, Drug Abuse and Drug Abuse RESEARCH 26 (1984). "The fact is, very little is known about the complex relationship which undoubtedly exists between drug abuse, worker performance and productivity or lack thereof, and how the work setting influences or is influenced by drug abuse." Id.

22. R.T.I. STUDY, supra note 13 , at 3 .

23. Id. Drug abuse cost $\$ 46.9$ billion and alcohol abuse cost $\$ 89.5$ billion. Id. President Reagan recently asserted that illegal drug use reduces American productivity by nearly $\$ 100$ billion each year, easily the highest such assessment to date. See Chicago Tribune, Feb. 9, 1988, \$1, at 5, col. 4. Precisely how the President arrived at his unprecedented estimate was not revealed. See id.

24. Brecher, Taking Drugs on the Job, Newsweek, Aug. 22, 1983, at 57.

25. In an affidavit submitted in National Treasury Employees Union v. Von Raab, 649 F. Supp. 380 (E.D. La. 1986), vacated, 816 F.2d 170 (5th Cir. 1987), cert. granted, 108 S. Ct. 1072 (1988), Dr. John P. Morgan described the Research Triangle Institute's study as "a kind of litany for the promoters of urine testing." Morgan characterized the study's method of calculating the costs of drug use as "preposterous," "manipulated," and "absurd." In Morgan's view, the study's results relied unduly upon a survey of annual household income for households in which one member had at one time used marijuana daily for one month. See R.T.I. STUdY, supra note 13, at 9.

26. Castro, supra note 16 , at 53 .

27. Id. Subsequent analysis, however, reveals that many transportation accidents attributed to employee drug use actually resulted from alcohol use or other causes. McBay, Efficient Drug Testing: Adtressing the Basic Issues, 11 Nova L. REv. 647 (1987). Recently, the Federal Railroad Administration (FRA) has fallen under increasing criticism for its poor accident investigations. See, e.g., id.; A. Hoffman, Steal This Urine Test: Fighting Drug Hysteria in America 122-24 (1987). On May 26, 1987, Dr. Dalbert J. Lacefield, supervisor of the Federal Aviation Administration's Forensic Toxicology Unit, pleaded guilty to preparing false drug screening reports in connection with his laboratory's participation in 1986 FRA accident investigations. A. Hoffman, supra, at 123.

28. See Cohen, Drugs in the Workplace, $45 \mathrm{~J}$. Clin. Psychiatry 4, 6 (1984) (work-related drug use increases the risks of injury, illness, and theft).

29. Castro, supra note 16 , at 59 ; see Rohan, supra note 16 , at 52 .

30. Castro, supra note 16 , at 58 . 
Although illegal drug use is a serious problem, its significance must be kept in proper perspective. By any standard of measurement, the more pervasive national drug problem is the abuse of alcohol, tobacco, and legal prescription and over-the-counter drugs. Each year 15,000 Americans die from misuse of legal prescription drugs. ${ }^{31}$ The National Institute on Drug Abuse (NIDA) estimates that legal prescription drugs cause sixty percent of emergency room admissions for drug overdoses and seventy percent of all drug-related deaths. ${ }^{32}$ Compared to the staggering number of deaths caused each year by alcohol and tobacco abuse, the yearly number of deaths attributable to illegal drug use appears small indeed. ${ }^{33}$ The Research Triangle Institute estimates that the costs imposed upon American industry by employee alcohol use are nearly two times that caused by illegal drug use. $^{34}$ Employees with an alcohol problem are an estimated 21 percent less productive than other employees. ${ }^{35}$ Yet despite the tremendous costs of alcohol use to American industry, very few drug testing programs currently screen employees for alcohol abuse. ${ }^{36}$

\section{B. The Employers' Response: The Use and Variety of Drug Testing.}

1. The Increased Implementation of Drug Testing Programs. Many employers have responded to workplace costs of employee drug use by implementing drug testing programs. Currently, about 40 percent of the Fortune 500 companies have instituted such programs or plan to do so, ${ }^{37}$ and some professional sports leagues have proposed player drug testing programs. ${ }^{38}$

31. Zeese, Drug Hysteria Causing Use of Useless Urine Tests, 11 Nova L. Rev. 815, 816 (1987).

32. Id.

33. See Thomas, supra note 14 , at 64 . In 1980 , alcohol killed 98,186 Americans, while tobacco killed about 300,000 . Id. Cocaine use resulted in 563 deaths nationwide in 1985. Id. There has never been a death caused by marijuana or long-term chronic marijuana use. Zeese, supra note 32 , at 816 .

34. R.T.I. STUDY, supra note 13, at 3. In 1980, employee alcohol abuse reduced American productivity by an estimated $\$ 50.6$ billion, while illegal drug use reduced productivity an estimated $\$ 25.7$ billion.

35. Id. at 8, 62. According to NIDA director Charles Schuster, "[t]here is no question that alcoholism in terms of social costs remains our number one problem. We can't lose sight of that because of our emphasis on drugs." Thomas, supra note 14, at 64 .

36. Employers perhaps ignore employee alcohol abuse because it traditionally carries less social stigma than illegal drug use. One commentator alleges that " $[t]$ he exclusion of alcohol from the scope of any drug testing program strips it of rationality." Wisotsky, The Ideology of Drug Testing, 11 Nova L. Rev. 763, 768 (1987). See Denenberg \& Denenberg, Drug Testing From the Arbitrator's Perspective, 11 Nova L. Rev. 371, 373-77 (1987).

37. Noel Dunivant \& Associates, Drug Testing in Major U.S. Corporations: A Survey of the Fortune 500, at 3-6 (1985) (available from Noel Dunivant \& Associates, Raleigh, N.C.) [hereinafter DUnivant SURVey]. In 1985, 18\% of surveyed companies tested for drugs, and an additional $20 \%$ planned to do so within two years. Id. In 1986, private companies which required urinalysis for all job applicants included IBM, DuPont, AT\&T, General Motors, Ford Motor Company, Exxon, Mobil, the New York Times, Capital Cities/ABC, Federal Express, Northeast Utilities, Shearson Lehman, TWA, Greyhound Lines, Alcoa, Lockheed, and United Airlines. National Institute of Justice, U.S. Dep't of Justice, Research in Brief, Employee Drug Testing Policies in Police Departments 2 (Oct. 1986) [hereinafter N.I.J. Survey]; Legislative Proposal, supra note 7 , at 271 .

38. See, e.g., Wong \& Ensor, Major League Baseball and Drugs: Fight the Problem or the Player?, 11 Nova L. Rev. 779 (1987). 
Federal, state, and local public employers have increasingly developed employee drug testing programs. Such programs for all federal agencies are currently being developed in response to an Executive Order issued by President Reagan. This order seeks to make the federal workforce a model for eliminating drug use in the national workplace by requiring implementation of such programs. ${ }^{39}$ In addition, drug testing programs are already in place in all four branches of the military, ${ }^{40}$ the Coast Guard, ${ }^{4 !}$ and several administrative agencies. ${ }^{42}$

In addition to requiring testing of certain public employees, government regulations require some private companies in highly regulated industries to test their employees for illegal drug use. For example, most railroads now test employees under regulations issued by the Federal Railroad Administration, ${ }^{43}$ and 90 percent of all nuclear power plants have instituted testing programs on a voluntary basis under guidelines issued by the Nuclear Regulatory Commission. ${ }^{44}$ In addition, many public utilities such as electric power companies and gas companies have voluntarily established drug testing programs, ${ }^{45}$ and a 1986 study revealed that nearly three-fourths of major police departments surveyed require urine testing for all job applicants. ${ }^{46}$

2. The Variety of Drug Testing Programs. When employers test and what they do with the results varies significantly among employers. Testing may be conducted randomly ${ }^{47}$ or upon a possible drug-related incident, such as an accident. ${ }^{48}$ Testing may be required for all job applicants, ${ }^{49}$ for all

39. Exec. Order No. 12,564, 3 C.F.R. 224 (1987), reprinted in 5 U.S.C. $\$ 7301$ app. (West Supp. 1987); see Willette, Drug Testing Programs, in National. Institute on Drug Abuse, U.S. Dep't of Health \& Human Services, Research Monograph No. 73, Urine Testing for Drugs of Abuse 12 (1986).

40. Willette, supra note 39 , at 5-6.

41. Id. at 7 .

42. The Federal Aviation Administration, Federal Railroad Administration, Drug Enforcement Administration, Federal Bureau of Investigation, U.S. Customs Service, Secret Service Uniformed Division, Central Intelligence Agency, and U.S. Postal Service have all implemented some type of employee testing program. Id. at 7-10.

43. Id. at 7, 8. For a discussion of the regulations issued by the Federal Railroad Administration and their application to employees of privately owned railroads, see Railway Labor Executives Ass'n v. Burnley, 839 F.2d 575, 577-79 (9th Cir.), cert. granted, 108 S. Ct. 2033 (1988).

44. Willette, supra note 39 , at 10 .

45. Id.

46. N.I.J. Survey, supra note 37 , at 2.

47. The four branches of the military and the Coast Guard utilize random testing programs. Willette, supra note 39 , at 5-7.

48. The Federal Railroad Administration drug testing regulations mandate drug and alcohol testing of train crew members after major train accidents, impact accidents, and fatal accidents. 49 C.F.R. § 219.201 (1987). See Railway Labor Executives Ass'n v. Burnley, 839 F.2d 575, 577 (9th Cir.), cert. granted, 108 S. Ct. 2033 (1988); see also Division 241 Amalgamated Transit Union v. Suscy, 538 F.2d 1264, 1267 (7th Cir.) (mandatory drug testing of bus drivers directly involved in serious accidents), cert. denied, 429 U.S. 1029 (1976).

49. Of 33 major police departments surveyed in 1986, 73\% screened all applicants for illegal drug use. N.I.J. SURveY, supra note 37, at 2. 
promotions, ${ }^{50}$ or as part of periodically required physicals. ${ }^{51}$ Some programs focus upon only specific types of employees. ${ }^{52}$ Of the Fortune 500 companies with testing programs, 80 percent test job applicants, 47 percent test employees after accidents, and 13 percent test employees at random. ${ }^{53}$

Drug testing programs also vary in terms of the actions taken toward employees testing positive for illegal drug use. Many simply dismiss all employees who test positive. ${ }^{54}$ A few testing programs, however, require employees who test positive to enter drug treatment or counseling programs paid for by the company or employee health insurance. ${ }^{55}$ About 30 percent of Fortune 500 companies with testing programs have established in-house employee assistance programs which refer drug abusing employees to hospitals or clinics for treatment. ${ }^{56}$

3. The Variety of Urine Tests. Drug testing programs may employ a variety of different types of tests to evaluate the physiological components of urine. Two of the most commonly used tests are the enzyme multiplied immunoassay test (EMIT), and the gas chromatography-mass spectrometer test (GC/MS). ${ }^{57}$ The tests differ significantly in chemical evaluation process, accuracy, and cost.

50. The U.S. Customs Service requires drug testing for all employees seeking transfer to sensitive positions. See National Treasury Employees Union v. Von Raab, 816 F.2d 170, 172 (5th Cir. 1987), cert. granted, 108 S. C. 1072 (1988).

51. The Federal Aviation Administration and the Secret Service Uniformed Division test employees for illegal drug use as part of required periodic physical examinations. Willette, supra note 39 , at 7,9 .

52. The U.S. Customs Service tests only personnel in "critical" positions, such as agents and chemists. Id. at 9. The Drug Enforcement Administration and the Federal Bureau of Investigation test only trainees, but they plan to extend testing incrementally to special agents and other critical positions. Id. at 8-9. Similarly, President Reagan recently ordered drug testing for all federal employees in "sensitive positions." Exec. Order No. 12,564, 3 C.F.R. 224, 226 (1987), reprinted in 5 U.S.C. $\$ 7301$ app. at 32 (West Supp. 1987). The actual scope of Reagan's somewhat vague language is not clear. The Director of the Federal Bureau of Prisons "decided that all positions, clerical or otherwise, are 'sensitive' under the Executive Order." American Fed'n of Gov't Employees v. Meese, 688 F. Supp. 547, 549 n.1 (N.D. Cal. 1988).

53. Dunivant Survey, supra note 37 , at 3-5.

54. In the military, for example, a positive test result for illegal drug use may provide sufficient ground for a dishonorable discharge. Willette, supra note 39 , at 6 .

55. In 1986, about one-fourth of major police departments surveyed indicated that treatment would be appropriate for drug-using officers instead of termination, depending upon the circumstances. N.I.J. SurveY, supra note 37 at 2.

56. Castro, supra note 16, at 57. The Mobil Oil Company claims that its typical employee assistance and drug treatment referral program is $70 \%$ to $75 \%$ successful in rehabilitating employees. Id.

57. These two tests are discussed for purposes of simplicity. There are several varieties of immunoassay tests, such as the radioimmunoassay test (RIA) used by the military in its testing programs. For purposes of this discussion, RIA and EMIT are not differentiated; the characteristics of the tests are similar in essential respects. For a discussion of the RIA test and others, see Dubowski, Drug-Use Testing: Scientific Perspectives, 11 Nova L. REv. 415, 446-84 (1987). 
The EMIT is highly popular because it is inexpensive $e^{58}$ and because it is portable, easy to administer on the job location. ${ }^{59}$ The EMIT relies upon a process known as competitive displacement and bonding, in which metabolites of illegal drugs present in the subject's urine displace preexisting bonds in the testing reagent and create new molecular configurations which indicate prior illegal drug use. ${ }^{60}$ For reasons discussed below, ${ }^{61}$ the EMIT suffers from inherent inaccuracy problems that make reliance on its results illadvised without confirmation by GC/MS testing. ${ }^{62}$

The much more expensive GC/MS test ${ }^{63}$ requires laboratory conditions to evaluate, ${ }^{64}$ but is highly accurate. ${ }^{65}$ In the GC/MS test, compounds present in urine are classified in a gas chromatographer and fragmented by bombarding them with high energy particles in a mass spectrometer. ${ }^{66}$ Different compounds split apart at different times, and the fragments' ionic weights vary. ${ }^{67}$ The time of fragmentation and the fragments' ionic weights are then compared to data stored in a computer library of compounds. ${ }^{68}$ If the fragmentation time and ionic weights match the computer data for a particular compound, a molecular "fingerprint" exists which is regarded as a highly accurate confirmation of that compound's presence. ${ }^{69}$ For optimum efficiency and accuracy, the EMIT should be used for initial screening. Positive EMIT results should then be subjected to GC/MS testing for more reliable confirmation.

\section{A Critical Review of the Employers' Response: The Scientific Limitations of Drug Testing Programs}

Is drug testing a reasonable response by employers to the problem of employee drug use? To answer this question, one must examine the scientific limitations of drug testing programs.

58. EMIT screening costs $\$ 10$ to $\$ 12$, depending upon the number of drugs screened for. Drug Testing Federal Employees: Hearings before the House Subcomm. on Human Resources of the Comm. on Post Office and Civil Service, 99th Cong., 2d Sess. 54 (1986) (statement of William W. Manders, Ph.D., Former Chief of Toxicology of the Armed Forces Institute of Pathology) [hereinafter Drug Testing Hearings].

59. Zeese, Marijuana Urinalysis Tests, 1 Drug Law ReP. 25, 25 (1983) [hereinafter Marijuana Urinalysis Tests]; Morgan, Problems of Mass Urine Screening for Misused Drugs, $16 \mathrm{~J}$. PSYCHOACTIVE DRugs 305, 306 (1984).

60. Morgan, supra note 59, at 306-08.

61. See infra notes 70-82 and accompanying text.

62. Even the manufacturers of the EMIT recommend confirmation of a positive EMIT test by a GC test alone, a GC/MS test, or another reliable test before any disciplinary action is taken. See, e.g., SYva Corp., Mem. No. G-7, Frequently Asked Questions About SYVA and Drug Abuse Testing (available from SYVA Corp.).

63. The cost for one GC/MS test ranges from $\$ 50$ to $\$ 100$. See, e.g., Drug Testing Hearings, supra note 58, at 12 (statement of Rep. Patricia Schroeder) ( $\$ 80$ estimate).

64. Kanter, Hollister \& Musumeci, Identification of Marijuana Use by Detection of delta-9-THC-11-OIC Acid by Using Thin-Layer Chromatography, 234 J. Chromatography 201 (1982).

65. See Dubowski, supra note 57, at 469-84.

66. Id.

67. Id.

68. Id.

69. Id. at 479 . 
1. The Inherent Inaccuracy of EMIT Testing. While the GC/MS test is quite accurate, the EMIT is to some degree inherently inaccurate, even when properly administered. The EMIT may yield a "false positive" by mistaking legal substances for illegal drugs due to "cross-reactivity,"70 which occurs when compounds present in urine react with the testing solution and displace its preexisting chemical bonds in the same manner as by-products of the targeted drug. ${ }^{71}$ Courts examining testing programs have recognized the serious accuracy problems of the EMIT, and many have suggested the need for confirmation by a more accurate test. ${ }^{72}$

The substances that the EMIT may mistake for various illegal drugs are numerous. Legal prescription and over-the-counter drugs such as aspirin, Contac, and Nyquil may cause a false positive result. ${ }^{73}$ Also, certain foods may trigger a false positive EMIT finding. For example, poppy seeds may be mistaken for opiates such as heroin and morphine, ${ }^{\mathbf{7 4}}$ and herbal teas may be confused with cocaine. ${ }^{75}$ Bodily enzymes with which the EMIT testing reagent may react are excreted through the urine. ${ }^{76}$ If an individual happens to discharge above-average amounts of those enzymes, the EMIT may register a false positive. ${ }^{77}$ The same problem may occur with the polar acids present in urine. The concentration and bonding properties of these acids vary with the body chemistry of the subject, and they may cross-react with the EMIT testing reagent. ${ }^{78}$ Some scientific evidence also suggests that higher concentrations of the pigment melanin present in the bodies of blacks and Hispanics may cause false positives. ${ }^{79}$ Because of cross-reactivity, it is

70. Morgan, supra note 59 , at 309 .

71. Id. at 309-12.

72. See, e.g., National Treasury Employees Union v. Von Raab, 649 F. Supp. 380, 389-90 (E.D. La. 1986), vacated, 816 F.2d 170 (5th Cir. 1987), cert. granted, 108 S. Ct. 1072 (1988); Lovvorn v. City of Chattanooga, 647 F. Supp. 875, 877 (E.D. Tenn. 1986), aff'd, 846 F.2d 1539 (6th Cir. 1988); Capua v. City of Plainfield, 643 F. Supp. 1507, 1521 (D.N.J. 1986); Storms v. Coughlin, 600 F. Supp. 1214,1217 (S.D.N.Y. 1984).

73. See Marijuana Urinalysis Tests, supra note 59, at 26; Morgan, supra note 59, at 309 . Although President Reagan volunteered to submit to drug testing as an example for others, he clearly recognized the danger of an incorrect positive result arising from his use of legal prescription drugs. According to a White House statement, the President's scheduled urinalysis was cancelled because "medication administered in connection with the [President's urological] examination could cause an inaccurate result." Legal Times, Sept. 1, 1986, at 11, col. 1 (commentary by Representative Donald Edwards).

74. Drug Testing Hearings, supra note 58, at 54 (statement of William Manders, Ph.D.). In an attempt to reduce the inaccuracy of drug testing caused by cross-reactivity, New York State Corrections Commissioner Thomas Coughlin banned poppy seeds from the New York prison system kitchens, commissaries, and vending machines. Chicago Tribune, Jan. 5, 1988, $\$ 1$ at 4, col. 1.

75. Legislative Proposal, supra note 7, at 269, 274 n.40.

76. Morgan, supra note 59 , at 312 .

77. Id. at 312 . The significance of this aspect of the cross-reactivity problem is not yet clear, but one study documented the appearance of the enzyme lysozyme at levels high enough to interfere with analysis of $10 \%$ of urine samples processed by one laboratory. Id.

78. Bible, Screening Workers For Drugs: The Constitutional Implications of Urine Testing in Public Employment, 24 AM. Bus. L. J. 309, 312 (1986).

79. See Dubowski, supra note 57 , at 516. 
estimated that 5 percent ${ }^{80}$ to 25 percent $^{81}$ of the positive results indicated by EMIT testing are incorrect, even if the EMIT is properly administered and evaluated. The EMIT may also register false negative readings, thus failing to identify those subjects who have used illegal drugs. ${ }^{82}$

2. The Administrative Inaccuracy of Drug Testing. While the EMIT is inaccurate even when properly administered, an EMIT positive result confirmed by GC/MS testing is quite reliable. ${ }^{83}$ This level of scientific accuracy, however, may be obtained only if testing administrators carefully observe strict processing procedures. Administrative errors may result from incorrect collection processes, sample mislabeling, improper training of administrators and lab technicians, dirty or uncalibrated laboratory equipment, or failure to keep urine specimens at the proper temperature. Since even the most accurate test is administered by fallible humans, errors are bound to occur in any large-scale testing program. ${ }^{84}$

The Center for Disease Control (CDC) in Atlanta conducted a nine year study of thirteen independent laboratories which revealed that some field testing programs had a false-positive rate ranging from 6 to 60 percent depending upon the drug being tested for ${ }^{85}$ The error rate for false negatives was even higher. ${ }^{86}$ The factors of operator error, inadequate testing protocol, and poor laboratory quality control are, of course, to some extent correctable. Nevertheless, the CDC study indicates that even established companies with professional technicians and comprehensive testing controls remain subject to remarkably high rates of error. The study concluded that these randomly selected laboratories displayed "serious

80. Note, Drug Testing: America's New Work Ethic?, 15 Stetson L. Rev. 883, 911 (1986) [hereinafter America's New Work Ethic?]. See also Allen \& Stiles, Specificity of the EMIT Drug Abuse Urine Assay Methods, 18(a) J. Clin. Toxicology 1043, 1062 (1981) (3\% to 5\% false positive rate).

81. Legal Times, supra note 73, at 11, col. 2 (commentary by Representative Donald Edwards).

82. See Allen \& Stiles, supra note 80 , at 1062.

83. See Dubowski, supra note 57 , at 474.

84. The U.S. military experience is a compelling example of the danger of inaccuracy in mass testing programs. The military drug screening program has been described as "an administrative nightmare of inaccurately labeled, switched, or contaminated specimens." Drug Testing Hearings, supra note 58, at 70 (statement of Representative Michael D. Barnes). The Department of Defense, to date the largest entity to implement mass drug testing, was forced to "reconsider punitive actions taken against 70,000 soldiers who had been disciplined on drug charges, because their drug tests had been faulty." Id. at 1 (statement of Hon. Gary L. Ackerman, Chairman of the Committee). Of 6,000 positive samples later retested by the Navy, "2,000 could not "be scientifically substantiated as accurate' and another 2,000 lacked some form of documentation." Bible, supra note 78, at 313.

A military investigation of the testing program found "a devastating error rate." Morgan, supra note 59, at 313. The investigation concluded "that most errors were not related to the tests themselves but to poor management, inadequate personnel, broken chain of custody, and faulty maintenance and transmission of reports and records." Id.

85. Hansen, Caudill \& Boone, Crisis in Drug Testing, 253 J. Am. Med. Ass'n 2382, 2382 (1985). The C.DC study reported the following false positive error rates: barbiturates, $0 \%$ to $60 \%$; amphetamines, $0 \%$ to $37 \%$; methadone, $0 \%$ to $36 \%$; cocaine, $0 \%$ to $6 \%$; and morphine, $0 \%$ to $10 \%$. Id.

86. See id. The CDC report revealed the following false negative error rates: barbiturates, $11 \%$ to $94 \%$; amphetamines, $19 \%$ to $100 \%$; methadone, $0 \%$ to $33 \%$; cocaine, $0 \%$ to $100 \%$; and morphine, $5 \%$ to $100 \%$. Id. 
shortcomings" in quality control even though they knew they were being monitored. ${ }^{87}$

3. Limitations on the Probative Value of Drug Testing. Having discussed the extent to which drug tests are able to detect illicit substances, it is useful, in order to assess the probative value of urinalysis, to examine what the tests do not show. First, even a correct positive test result for marijuana use does not prove that the test subject ever used marijuana himself. Depending upon what concentration of an illicit substance metabolite constitutes a positive test result, a positive result could be caused by the subject's passive inhalation of smoke from marijuana used by someone else. ${ }^{88}$

Second, urine testing shows neither intoxication ${ }^{89}$ nor actual job impairment. ${ }^{90}$ Rather, it indicates only that the subject ingested the detected drug within the preceding days or weeks. ${ }^{91}$ The tests cannot identify the presence of an illicit drug directly; instead, they determine prior use of an illicit drug inferentially by screening for the presence of its by-products in the urine. ${ }^{92}$

For instance, prior use of marijuana is determined by screening not for the intoxicating chemical itself, tetrahydrocannabinol (THC), but for its by-

87. Id. at 2386.

88. See Dubowski, supra note 57, at 512; Cone \& Johnson, Contact Highs and Urinary Cannabinoid Excretion After Passive Exposure to Marijuana Smoke, 40 Clin. Pharmacol. Therap. 247-56 (1986); Zeidenberg, Bordon \& Nahas, Marijuana Intoxication by Passive Inhalation: Documentation by Detection of Urinary Metabolites, 134 Aм. J. Psychology 76 (1977).

89. Cohen, Drugs in the Workplace, 45:12 J. Clin. Psychiatry 4, 5 (1984) ("A positive urine test for marijuana does not necessarily mean one is intoxicated."). The Federal Railroad Administration has recognized that urinalysis does not measure current impairment, and recommends in its drug testing regulations that a blood test be administered along with urinalysis in order to better insure that a positive test result indicates current impairment. See 49 C.F.R. \& 219.309(b)(2) (1986); see also Railway Labor Executives Ass'n v. Burnley, 839 F.2d 575, 597.98 (9th Cir.) (Alarcon, J., dissenting), cert. granted, 108 S. Ct. 2033 (1988).

90. Lundberg, Mandatory Unindicated Unine Drug Screening: Still Chemical McCarthyism, 256 J.A.M.A. 3003,3004 (1986) ("Under no circumstances can impairment be diagnosed or even presumed from a urine test result."); Legislative Proposal, supra note 7, at 274 n.45 ("The effects of drug use have not been correlated with specific concentrations of drug metabolites in urine specimens."). Bible, supra note 78 , at 319 .

It could also be noted that the claim that marijuana use reduces productivity is somewhat suspect. A recent assessment of three studies of marijuana use concluded that chronic users showed no evidence of intellectual or neurological damage, no changes in personality, and no loss of will to participate in society. Marijuana, The Harvard Medical School Mental Health Letter, Nov. 1987, at 1, 3. In addition, analyses of marijuana intoxication have revealed little or no loss of motor coordination. See Wisotsky, supra note 36, at 775; Zeese, supra note 31, at 817. See also Morgan, supra note 59:

[T] ]he descriptions of supposed malfunction all ignore an experimental and anecdotal listing of drug use that improves work performance. Both ancient Peruvian miners and modern Jamaican workers have been characterized as working better under drug influence. A variety of studies have indicated that stimulant drug use may increase productivity in a variety of settings. Modern cultural belief and conventional wisdom demand that such evidence be explained away or ignored.

Morgan, supra note 39, at 306 (citations omitted).

91. See Dubowski, supra note 57, at 530 . (For example, approximate duration of detectability of cocaine is two to five days; of benzodiazepines, three to ten days.).

92. See generally id. at $446-84$. 
product metabolite, ${ }^{93}$ which appears only after THC breaks down and its intoxicating effects disappear. ${ }^{94}$ Because the target metabolite does not appear until intoxication passes, testing "can establish only marijuana use, not intoxication."95 The metabolite is detectable in the body of a casual user for several days and even longer in the chronic user. ${ }^{96}$ The use of other drugs can have a similar effect, permitting detection of by-products long after intoxication has passed. ${ }^{97}$

Because urine testing cannot detect present intoxication or the time that the illegal drugs were taken, it cannot measure job impairment accurately. These serious shortcomings necessarily permit an employer's drug testing to scrutinize an employee's off-duty drug use, whether or not that use impairs her job performance. ${ }^{98}$

In addition, testing may fail to identify those drug-using employees who avoid or manipulate tests. If employees learn of the testing date, drug users may merely abstain from drug use in order to test negative. Drug users may also neutralize evidence of drug use by adulterating their samples with substances as common as table salt. ${ }^{99}$ A drug-using employee may even substitute a drug-free urine sample for her own.

The most telling limitation on the probative value of drug testing is its statistical unreliability. The likelihood that a given positive result is correct depends entirely upon the extent to which the tested group actually uses drugs. If one assumes that 5 percent ${ }^{100}$ of a group of employees uses illegal drugs and that an employer uses a drug testing program with 95 percent

93. Bible, supra note 78 , at 311 . Urinalysis for marijuana use targets the THC metabolite 11 nor-delta-9-THC-9-carboxylic acid. Id.

94. Id. at 311. The THC itself has a life of only two to three hours, the length of marijuana intoxication. Id. at 311 n.7.

95. Id. at 319 (emphasis in original).

96. See Dubowski, supra note 57 , at $\mathbf{5 3 0 .}$

97. Id.

98. Cohen, supra note 95 , at 5 . Whether government employers may forbid off-duty drug use without proof of job impairment is debated. See generally America's New Work Ethic?, supra note 80, at 898-90 I (discussing the scope of government's right to regulate its employees' private lives). The Civil Service Reform Act provides that government supervisors must not "discriminate for or against any employee or applicant for employment on the basis of conduct which does not adversely affect the performance of the employee or applicant or the performance of others." 5 U.S.C. $\S 2302$ (b)(10) (1982). One commentator recently asked: "If the employer can fire a person for smoking marijuana on a Saturday night, what prevents him from regulating such things as off-duty alcohol consumption or even sleeping habits in an effort to ensure that the employee works to his full capacity?" Legislative Proposal, supra note 7, at 279 .

In the public sector, the courts seem willing to allow employers to forbid off-duty use altogether when the job affects public safety and when the agency's integrity in the eyes of the public is necessary for it to function effectively. See, e.g., City of Palm Bay v. Bauman, 475 So. 2d 1322, 1326 (Fla. Dist. Ct. App. 1985) (allowing prohibition of off-duty drug use of police and firefighters because of potential dangers their jobs entail); Bostic v. McClendon, 650 F. Supp. 245, 250 (N.D. Ga. 1986) ("The open violation of narcotic laws by its officers does hinder the police department's ability to effectively carry out its statutory responsibilities, and therefore the police department does have a legitimate, if lesser, interest in preventing such off-duty conduct.").

99. See Morgan, supra note 59, at 309.

100. This figure lies in the upper range of the estimated prevalence of drug use among employees according to Rohan, supra note 16 , at 52. 
accuracy to screen the group, ${ }^{101}$ the employer's "accurate" program will yield one false positive result for every correct positive result. ${ }^{102}$ If only 2 percent of the group uses illegal drugs, three out of every four positive results will be incorrect. ${ }^{103}$ If all 2.8 million federal workers are tested as suggested by the President's Commission on Organized Crime, an estimated 140,000 workers will be accused and disciplined unjustly. ${ }^{104}$

\section{III}

\section{Drug Testing and the Fourth Amendment}

But even if the front door of the house is no longer protected by the Constitution, surely it had been thought until now that the bathroom door is. ${ }^{105}$

\section{A. The Purpose and Scope of the Fourth Amendment}

Against this factual background, careful application of fourth amendment doctrine to random drug testing programs in the public sector reveals that such programs are unconstitutional searches and seizures under most circumstances. The fourth amendment to the United States Constitution provides:

The right of the people to be secure in their persons, houses, papers, and effects, against unreasonable searches and seizures, shall not be violated, and no Warrants shall issue, but upon probable cause, supported by Oath or affirmation, and particularly describing the place to be searched and the persons or things to be seized. ${ }^{106}$

"The fundamental command of the Fourth Amendment is that searches and seizures be reasonable . . . "107 The amendment prohibits only unreasonable searches and seizures. ${ }^{108}$ What is reasonable, however, depends on the context of the search. ${ }^{109}$ The prevailing test for "reasonableness" was set forth by the Supreme Court in Bell $v$. Wolfush:110 "The test of reasonableness under the Fourth Amendment is not capable of precise

101. This is a generous estimate, given reported drug testing error rates. See supra notes $70-87$ and accompanying text.

102. Lundberg, supra note 89 , at 3004 .

103. This analysis is illustrated by the following table:

\begin{tabular}{cc} 
Prevalence, \% & $\begin{array}{c}\text { Predictive Value of a } \\
\text { Positive Result, \% }\end{array}$ \\
\cline { 2 - 2 } 0.1 & 2 \\
1.0 & 16 \\
2.0 & 28 \\
5.0 & 50 \\
10.0 & 68 \\
50.0 & 95
\end{tabular}

Id. at 3003. See also P. Chapin, Drug Testing: A Probabilistic Assessment (1986).

104. Drug Testing Hearings, supra note 58, at 39.

105. District of Columbia v. Little, 178 F.2d 13, 18 (D.C. Cir. 1949), aff'd, 339 U.S. 1 (1950).

106. U.S. Const. amend. IV.

107. New Jersey v. T.L.O., 469 U.S. 325, 340 (1985).

108. Carroll v. United States, 267 U.S. 132, 147 (1925).

109. New Jersey v T.L.O., 469 U.S. 325, 337 (1985).

110. 441 U.S. 520 (1979). 
definition or mechanical application. In each case it requires a balancing of the need for the particular search against the invasion of personal rights that the search entails." 11

It is difficult to predict with certainty, however, the exact test the Supreme Court will use when confronted with the testing of public employees. Most recently, in $O^{\prime}$ Connor $v$. Ortega, ${ }^{112}$ the Court indicated that searches of

government employees for noninvestigatory, work-related purposes, as well as for investigations of work-related misconduct, should be judged by the standard of reasonableness under all the circumstances. Under this reasonableness standard, both the inception and the scope of the intrusion must be reasonable. ${ }^{113}$

The Court explicitly did not, however, "address the proper Fourth Amendment analysis for drug and alcohol testing of employees."114 It is difficult to discern what independent meaning is communicated by this most recent formulation of the test. 115 Depending upon the context, it may be impossible to determine whether a search is justified at its inception without first considering the scope of the search. For example, the "scope" of a drug test is the compelled tender of a urine specimen. It may be compelled under direct or indirect observation. All of these considerations seem appropriate to take into account when determining whether the drug test was justified at its inception. ${ }^{116}$

Whether the inception and scope of a search are reasonable would seem in the final analysis to depend upon a balancing of the interests outlined in Bell. Even if the Court utilizes the recent $O^{\prime}$ Connor formulation, it appears inevitable that the same balancing of governmental interests against individual privacy rights articulated in Bell will in the end determine the constitutionality of public employee drug testing programs. Thus, to determine the constitutionality of such drug testing, the state interests advanced by testing must be balanced against its intrusiveness upon

111. Id. at 559 .

112. 107 S. Ct. 1492 (1987).

113. Id. at 1502-03.

114. Id at 1504 n.2. O'Connor also may be distinguished factually. In $O^{\prime}$ Connor, a plurality concluded that a public employer could search an employee's office and desk without reasonable suspicion of illegal conduct. Id. at 1502 . The plurality observed, however, that such a search is a relatively limited intrusion upon employee privacy because it involves a search of office space, not the home. Id. Moreover, the plurality reasoned, an "employee may avoid exposing personal belongings at work by simply leaving them at home." Id. at 1502 . In contrast, drug testing involves a search of the person, not an office. One cannot avoid such a search by leaving one's urine at home.

115. See id. at $1514 \mathrm{n} .14$ (Blackmun, J., dissenting) ("I would fault the plurality for its failure to give much substance to the standard it has borrowed almost verbatim from New Jersey v. T.L.O."); id. at 1505 (Scalia, J., concurring) ("I would object to the formulation of a standard so devoid of content that it produces rather than eliminates uncertainty in this field"); Feliciano v. City of Cleveland, 661 F. Supp. 578, 587 (N.D. Ohio 1987) (" $O$ 'Connor's standard of reasonableness for employer searches, finally articulated as 'reasonableness under the circumstances,' is a curious concept indeed. The Court offers little guidance about how this concept shall be given content."). The "inception" and "scope" language is derived from Terry v. Ohio, 392 U.S. 1, 20 (1968), and was used again by the Court in New Jersey v. T.L.O., 469 U.S. 325, 341 (1985), but in both Terry and T.L.O. the Court attempted to give content to the language by tying it more carefully to the context of the search involved.

116. For an example of this difficulty, see infra note 250 . 
employees' privacy interests; the greater the intrusion occasioned by the search, the greater must be the governmental interest in conducting the search. ${ }^{117}$

\section{B. The Threshold Issue: A Drug Test Is a Search}

The threshold issue in fourth amendment analysis is whether a drug test is a search. If the test is not a search, then no fourth amendment objection arises, which obviates the need to balance state and individual privacy interests. Whether a drug test is a search generally depends upon whether there exists a "reasonable expectation of privacy" in the act of urination. ${ }^{118}$

Evaluating reasonable expectations of privacy for purposes of determining whether an intrusion constitutes a fourth amendment search is an abstract, non-case-specific inquiry which focuses upon whether society is prepared to recognize that the employee has a legitimate expectation of privacy from drug tests. ${ }^{119}$ In response to this question, the courts have uniformly found that a drug test is a search within the meaning of the fourth amendment. ${ }^{120}$ Despite

117. See Sec. \& Law Enforcement Emp. Dist. C.82 v. Caney, 737 F.2d 187, 208 (2d Cir. 1984). See also Winston v. Lee, 470 U.S. 753, 766 (1985).

118. See Katz v. United States, 389 U.S. 347 (1967).

119. Id. at 361 .

120. See, e.g., Policeman's Benevolent Ass'n v. Township of Washington, 850 F.2d 133, 135-36 (3d Cir. 1988); Penny v. Kennedy, 846 F.2d 1563, 1565 (6th Cir. 1988); Lovvorn v. City of Chattanooga, 846 F.2d 1539 (6th Cir. 1988); Rushton v. Nebraska Pub. Power Dist., 844 F.2d 562, 566 (8th Cir. 1988); Railway Labor Executives Ass'n v. Burnley, 839 F.2d 575, 579-80 (9th Cir.), cert granted, 108 S. Ct. 2033 (1988); Jones v. McKenzie, 833 F.2d 335, 338 (D.C. Cir. 1987); Everett v. Napper, 833 F.2d 1507, 1511 (11th Cir. 1987); National Treasury Employees Union v. Von Raab, 816 F.2d 170, 175 (5th Cir. 1987), cert. granted, 108 S. Ct. 1072 (1988); National Fed'n of Fed. Employees v. Weinberger, 818 F.2d 935, 942 (D.C. Cir. 1987); McDonell v. Hunter, 809 F.2d 1302, 1307 (8th Cir. 1987); Shoemaker v. Handel, 795 F.2d 1136, 1142 (3d Cir.) (urinalysis implicitly found a search when court discussed and applied necessarily subsequent fourth amendment analysis), cert. denied, 107 S. Ct. 577 (1986); Division 241 Amalgamated Transit Union v. Suscy, 538 F.2d 1264, 1267 (7th Cir.), cert. denied, 429 U.S. 1029 (1976); Harmon v. Meese, 3 Individual Empl. Rights Cas. (BNA) 865, 866-67 (D.D.C. July 29, 1988); American Fed'n of Gov't Employees v. Meese, 688 F. Supp. 547, 550-51 (N.D. Cal. 1988); National Fed'n of Fed. Employees v. Carlucci, 680 F. Supp. 416, 430 (D.D.C. 1988); American Fed'n of Gov't Employees v. Dole, 670 F. Supp. 445, 447 (D.D.C. 1987); Taylor v. O'Grady, 669 F. Supp. 1422, 1434 (N.D. Ill. 1987); Amalgamated Transit Union, Local 1277 v. Sunline Transit Agency, 663 F. Supp. 1560, 1566 (C.D. Cal. 1987); Feliciano v. City of Cleveland, 661 F. Supp. 578, 586 (N.D. Ohio 1987); Mullholland v. Department of Army, 660 F. Supp. 1565, 1569 (E.D. Va. 1987); American Fed'n of Gov't Employees v. Weinberger, 651 F. Supp. 726, 732 (S.D. Ga. 1986); Bostic v. McClendon, 650 F. Supp. 245, 248-49 (N.D. Ga. 1986); Capua v. City of Plainfield, 643 F. Supp. 1507, 1513 (D.N.J. 1986); Allen v. City of Marietta, 601 F. Supp. 482, 488-89 (N.D. Ga. 1985); Patchogue-Medford Congress of Teachers v. Board of Educ., 119 A.D.2d 35, 37-38, 505 N.Y.S.2d 888, 890 (N.Y. App. Div. 1986), aff'd, 70 N.Y.2d 57, 67-68, 510 N.E.2d 325, 329-30, 517 N.Y.S.2d 456, 460-61 (1987); Turner v. Fraternal Order of Police, 500 A.2d 1005, 1007-08 (D.C. 1985); Caruso v. Ward, 133 Misc. 2d 544, 546-47, 506 N.Y.S.2d 789, 792 (N.Y. Sup. Ct. 1986), aff'd, 131 A.D.2d 214, 520 N.Y.S.2d 551 (N.Y. App. Div. 1987); City of Palm Bay v. Bauman, 475 So. 2d 1322, 1324-25 (Fla. Dist. Ct. App. 1985). Even mandatory urinalysis of prisoners has been found to constitute a search. See, e.g., Spence v. Farrier, 807 F.2d 753, 755 (8th Cir. 1986); Tucker v. Dickey, 613 F. Supp. 1124, $1127-28$ (W.D. Wis. 1985); Storms v. Coughlin, 600 F. Supp. 1214, 1217-18 (S.D.N.Y. 1984).

A few courts have found that a drug test is a seizure, rather than, or in addition to being a search. See, e.g., National Treasury Employees Union v. Von Raab, 649 F. Supp. 380, 386-87 (E.D. La. 1986) (search and seizure), vacated, 816 F.2d 170 (5th Cir. 1987), cert. granted, $108 \mathrm{~S}$. Ct. 1072 (1988); McDonell v. Hunter, 612 F. Supp. 1122, 1127 (S.D. Iowa 1985), aff'd as modified, 809 F.2d 1302 (8th 
the novelty of the technology, the courts have recognized that drug testing implicates central fourth amendment values, and that individuals have legitimate expectations of privacy in the act of urination. ${ }^{121}$

\section{The Individual Interests: The Intrusiveness of Drug Testing}

Once courts determine that a drug test is a search, they must balance the intrusiveness of the search against the government's need for the information

Cir. 1987). In only one decision has a judge suggested that the reasonableness of a drug test depends upon its characterization as a search or seizure. See Turner v. Fraternal Order of Police, 500 A.2d 1005, 1010-11 (D.C. 1985) (Nebeker, J., concurring). After finding that urinalysis constitutes a seizure, $i d$. at 1010 , Judge Nebeker analogized the seizure of urine to seizures of personal physical characteristics routinely exposed to the public, such as the voice or handwriting. Id. at 1011. Judge Nebeker concluded that the seizure of urine through testing does not violate the fourth amendment because an individual retains no possessory interest in her urine when she discards it, id, and routinely exposes her urine to the public by flushing it into a public sewer.

Judge Nebeker's analysis, however, is unacceptably simplistic. An individual typically regards urination as a private bodily function, and reasonably expects her urine to become indistinguishible from that of others when she flushes it down the drain. She certainly does not reasonably expect that her urine, once discarded, may be seized by the government and scrutinized for the physiological data it may reveal. Moreover, the seizure of an individual's urine for analysis is qualitatively much more intrusive than seizures of immutable bodily characteristics such as voice patterns or handwriting that are routinely exposed to the public. Cf. American Fed'n of Gov't Employees v. Weinberger, 651 F. Supp. 726, 733 (S.D. Ga. 1986) (seizures of immutable bodily characteristics such as fingerprints, fingernail clippings, and hair clippings not as intrusive as a urine test).

121. Interestingly, several courts have noted in dicta that drug testing conducted pursuant to a required medical examination minimizes the intrusiveness of the search, makes the search reasonable, or does not implicate the fourth amendment at all. See, e.g., Jones v. McKenzie, 833 F.2d 335, 340 (D.C. Cir. 1987) (" [T] his case involves only testing that is conducted as part of a routine, reasonably required, annual medical examination. This has the effect of ensuring that the intrusion on the employee's privacy is minimized."); City of Palm Bay v. Bauman, 475 So.2d 1322, 1325 (Fla. Dist. Ct. App. 1985) (urinalysis absent reasonable suspicion violates the fourth amendment "except for urine testing performed as a part of physical examinations required by City Personnel Policy for initial employment, or annually, or at other designated career times"); Caruso v. Ward, 133 Misc. 2d 544, 555,506 N.Y.S.2d 789, 798 (N.Y. Sup. Ct. 1986) ("No one questions the right to establish as a condition of employment the requirement of a health checkup, ... . [b]ut routine health examinations are far different than testing for the specific purpose of finding evidence of drugs."), aff'd, 131 A.D.2d 214, 520 N.Y.S.2d 551 (N.Y. App. Div. 1987); McDonell v. Hunter, 612 F. Supp. 1122,1130 n.6 (S.D. Iowa 1985) ("The Fourth Amendment, however, does not preclude taking a body fluid specimen as part of a pre-employment examination or as part of any routine periodic physical examination that may be required of employees . ..."), aff'd as modified, 809 F.2d 1302 (8th Cir. 1987).

The courts have not offered any reasons why drug testing conducted pursuant to a required medical examination escapes serious fourth amendment scrutiny. Two considerations perhaps support the courts' apparently lenient attitude toward such testing. First, the medical examination context is quite removed from the criminal or investigatory context in which fourth amendment searches typically occur. Second, because doctors commonly ask patients to supply urine samples for routine medical testing, an individual attending a physical examination possesses a somewhat diminished expectation of privacy in his urine.

Nevertheless, to justify a virtual exemption from fourth amendment constraints, such testing must remain true to its avowed purpose; results must be used only for medical trealment, rather than adverse employment action or criminal prosecution. Employers should not be permitted to disguise unconstitutional searches of their employees as medical examinations. Thus, in cases challenging drug tests conducted during a required physical examination, courts should inquire whether the drug testing in question was part of a bona fide medical examination. Relevant questions include: How are the test results used? What substances are tested for? When was the program instituted? Did particular employees demonstrate symptoms of drug use or dependency prior to the commencement of testing? Were all employees tested? 
that the search will reveal. ${ }^{122}$ In focusing on the intrusiveness of a search, courts first examine the context of an individual's expectation of privacy. ${ }^{123}$ What is reasonable in one context may not be reasonable in another. ${ }^{124}$ Although most public employees legitimately have very strong expectations of privacy both in the act of urination and in its contents, an employee's expectations of privacy may be diminished if she enters an occupation which requires significant preparedness and discipline, such as the military, ${ }^{125}$ intensely regulated industries, ${ }^{126}$ nuclear power plants, ${ }^{127}$ prisons, ${ }^{128}$ public transportation, ${ }^{129}$ or law enforcement. ${ }^{130}$ On the other hand, public employees whose occupations do not directly implicate public safety or other similar governmental interests retain the same level of privacy enjoyed by the ordinary citizen. ${ }^{131}$

After courts assess the context of the employee's expectations of privacy, they examine the intrusiveness of the search. Because an individual generally has the highest expectations of privacy in her body, searches violating the integrity of the body are greater invasions of privacy than inspections of personal effects. ${ }^{132}$ The Supreme Court has observed that "even a limited search of the person is a substantial invasion of privacy."'133

There are three compelling reasons why drug tests are very intrusive, even when compared with other bodily searches. First, the tests reveal not only past drug use, but also numerous other physiological facts that are of no legitimate interest to the employer. While exposing past illegal drug use,

122. O'Connor v. Ortega, 107 S. Ct. 1492, 1497 (1987) (plurality opinion). Traditional fourth amendinent analysis would also inquire whether a warrant is required before the search may be conducted. In $O$ 'Connor, the Court indicated that "the realities of the workplace . . strongly suggest that a warrant requirement would be unworkable." Id. at 1500 . Accordingly, the Court proceeded directly to a balancing analysis. Id.

123. Id. at 1497. Accord United States v. Thomas, 729 F.2d 120, 123-24 (2d Cir.), cert. denied, 469 U.S. 846 (1984); Turner v. Fraternal Order of Police, 500 A.2d 1005, 1007 (D.C. 1985).

124. Committee for GI Rights v. Callaway, 518 F.2d 466, 476 (D.C. Cir. 1975 ).

125. See, e.g., id. at 477.

126. See, e.g., Policeman's Benevolent Ass'n v. Township of Washington, 850 F.2d 133, 135, 141 (3d Cir. 1988); Shoemaker v. Handel, 795 F.2d 1136, 1142 (3d Cir.), cert. denied, 107 S. Ct. 577 (1986).

127. See, e.g., Rushton v. Nebraska Pub. Power Dist., 844 F.2d, 562, 566 (8th Cir. 1988).

128. See, e.g., McDonell v. Hunter, 809 F.2d 1302, 1308 (8th Cir. 1987).

129. See, e.g., Division 241 Amalgamated Transit Union v. Suscy, 538 F.2d 1264, 1267 (7th Cir.), cert. denied, 429 U.S. 1029 (1976).

130. See, e.g., Policeman's Benevolent Ass'n v. Township of Washington, 850 F.2d 133, 141 (3d Cir. 1988); Caruso v. Ward, 133 Misc. 2d 544, 548, 506 N.Y.S.2d 789, 793 (N.Y. Sup. Ct. 1986), aff'd, 131 A.D.2d 214, 520 N.Y.S.2d 551 (N.Y. App. Div. 1987); Turner v. Fraternal Order of Police, 500 A.2d 1005, 1008 (D.C. 1985); City of Palm Bay v. Bauman, 475 So. 2d 1322, 1324 (Fla. Dist. Ct. App. 1985).

131. See, e.g., Harmon v. Meese, 3 Individual Empl. Rights Cas. (BNA) 865, 867-68 (D.D.C. July 29, 1988); American Fed'n of Gov't Employees v. Meese, 688 F. Supp. 547, 550-51 (N.D. Cal. 1988). But see Patchogue-Medford Congress of Teachers v. Board of Educ., 119 A.D.2d 35, 40, 505 N.Y.S.2d 888, 891 (N.Y. App. Div. 1986), aff'd, 70 N.Y.2d 57, 68-69, 510 N.E.2d 325, 330, 517 N.Y.S.2d 456, 461-62 (1987) (reasonable suspicion, not probable cause, is appropriate standard for drug testing of teachers).

132. See New Jersey v. T.L.O., 469 U.S. 325, 337-38 (1985); Capua v. City of Plainfield, 643 F. Supp. 1507, 1514 (D.N.J. 1986).

133. T.L.O., 469 U.S. at 337. 
drug tests also expose the use of legally prescribed medications, including oral contraceptives and medication to treat physical and psychiatric conditions previously recognized as within the traditional confidentiality of medical records. ${ }^{134}$ Drug testing also exposes otherwise private medical conditions, including diabetes, epilepsy, urinary tract infections, venereal disease, and pregnancy. ${ }^{135}$

Second, drug tests necessarily scrutinize a broad array of off-duty activities. As observed in American Federation of Government Employees $v$. Weinberger, ${ }^{136}$ " $[\mathrm{t}] \mathrm{h}$ ese tests enable the individual or organization administering them to monitor the off-duty conduct of employees, and represent a technological advance that ... could threaten much of the privacy most citizens now take for granted." 137

Third, the manner in which urine specimens are obtained is quite intrusive. Urination is a personal bodily function usually performed in solitude. In fact, many municipal ordinances prohibit the act in public. ${ }^{138}$ Some testing programs require a government official's direct observation of the act of urination to assure the accuracy of the test and to prevent adulteration of the samples. ${ }^{139}$ Urination under the direct observation of another "necessarily includes exposing one's private parts, an experience which even if courteously supervised can be humiliating and degrading." 140

Even if urine samples are not collected under direct observation, many testing programs require at least indirect observation, which may be equally

134. See, e.g., Rushton v. Nebraska Pub. Power Dist., 844 F.2d 562, 566 (8th Cir. 1988); Shoemaker v. Handel, 795 F.2d 1136, 1144 (3d Cir.), cert. denied, 107 S. Ct. 577 (1986); Capua v. City of Plainfield, 643 F. Supp. 1507, 1515 (D.N.J. 1986); McDonell v. Hunter, 612 F. Supp. 1122,1127 (D. Iowa 1985), aff'd as modified, 809 F.2d 1302 (8th Cir. 1987). See also Drug Testing Hearings, supra note 58, at 2 (statement of Representative Ackerman); id. at 39 (statement of James Pierce, President, National Federation of Federal Employees).

135. Drug Testing Hearings, supra note 58, at 2, 39.

136. 651 F. Supp. 726 (S.D. Ga. 1986).

137. Id. at 732. See also Jones v. McKenzie, 833 F.2d 335, 339 (D.C. Cir. 1987) ("Because drug tests often furnish information about employee activities occurring outside of working hours, such tests may provide Government officials with a periscope through which they can peer into an individual's behavior in her private life, even in her own home."); Capua v. City of Plainfield, 643 F. Supp. 1507, 1511 (D.N.J. 1986) (drug testing is "a form of surveillance" which "reports on a person's off-duty activities just as surely as [if] someone had been present and watching”).

138. See, e.g., National Treasury Employees Union v. Von Raab, 816 F.2d 170, 175 (5th Cir. 1987), cert. granted, 108 S. Ct. 1072 (1988); Capua v. City of Plainfield, 643 F. Supp. 1507, 1514 (D.N.J. 1986).

139. For examples of cases in which challenged testing programs required direct observation, see Lovvorn v. City of Chattanooga, 647 F. Supp. 875 (E.D. Tenn. 1986), aff'd, 846 F.2d 1539 (6th Cir. 1988); Capua v. City of Plainfield, 643 F. Supp. 1507 (D.N.J. 1986); Caruso v. Ward, 133 Misc. 2d 544, 506 N.Y.S.2d 789 (N.Y. Sup. Ct. 1986), aff'd, 131 A.D.2d 214, 520 N.Y.S.2d 551 (N.Y. App. Div. 1987).

140. Caruso v. Ward, 133 Misc.2d 544, 548, 506 N.Y.S.2d 789, 793 (N.Y. Sup. Ct. 1986), aff'd, 131 A.D.2d 214, 520 N.Y.S.2d 551 (N.Y. App. Div. 1987). See also National Treasury Employees Union v. Von Raab, 649 F. Supp. 380, 387 (E.D. La. 1986), vacated, 816 F.2d 170 (5th Cir. 1987), cert. granted, 108 S. Ct. 1072 (1988); Lovvorn v. City of Chattanooga, 647 F. Supp. 875, 880 (E.D. Tenn. 1986), aff'd, 846 F.2d 1539 (6th Cir. 1988); Capua v. City of Plainfield, 643 F. Supp. 1507, 1514 (D.N.J. 1986). 
embarrassing and insulting. ${ }^{141}$ Regardless of whether testing requires any observation, the experience of being forced to produce a urine sample at the behest of an employer offends normal expectations of dignity. As one court noted, "the very taking of the sample makes for a quite substantial intrusion that could not be negated even if an employee were allowed to produce his urine sample in the privacy of an executive washroom, with no observation whatsoever."142 Drug tests have been described as more intrusive than a search of the home; ${ }^{143}$ equal to ${ }^{144}$ or more intrusive ${ }^{145}$ than a blood test; and equal to the intrusiveness of a strip search ${ }^{146}$ or even a body cavity search. ${ }^{147}$ In light of the private bodily information that drug testing can reveal, the potential days of off-duty activity it can scrutinize, and the highly offensive and degrading process of collecting the specimen itself, it is fair to conclude that drug testing is a highly invasive search that requires a proportionally weighty state interest to justify it.

\section{The Governmental Interests}

The magnitude of the invasion upon individual liberties caused by drug testing must be balanced against the governmental interests furthered by the tests. Three distinct governmental interests have been advanced in support of drug testing: (1) the identification of drug-using employees to further efficiency and safety in the workplace; (2) the integrity of the particular employment institution as perceived by the public; and (3) the enforcement of the criminal laws against drug trade and use by reducing the demand for illegal drugs. While these are certainly legitimate objectives of governmental

141. See, e.g., Taylor v. O'Grady, 669 F. Supp. 1422, 1434 (N.D. Ill. 1987) (“Compelling an individual to urinate at a particular time and place into a cup for subsequent chemical analysis can be and was for [this plaintiff] an extreme intrusion and invasion into her most narrow sphere of personal privacy."); American Fed'n of Gov't Employees v. Weińberger, 651 F. Supp. 726, $733-34$ (S.D. Ga. 1986).

142. American Fed'n of Gov't Employees v. Weinberger, 651 F. Supp. 726,734 (S.D. Ga. 1986).

143. National Treasury Employees Union v. Von Raab, 649 F. Supp. 380, 386 (E.D. La. 1986), vacated, 816 F.2d 170 (5th Cir. 1987), cert. granted, 108 S. Ct. 1072 (1988).

144. See, e.g., Amalgamated Transit Union, Local 1277 v. Sunline Transit Agency, 663 F. Supp. 1560, 1566 (C.D. Cal. 1987); American Fed'n of Gov't Employees v. Weinberger, 651 F. Supp. 726 , 733 (S.D. Ga. 1986); Bostic v. McClendon, 650 F. Supp. 245, 249 (N.D. Ga. 1986); Tucker v. Dickey, 613 F. Supp. 1124, 1129 (D. Wis. 1985); McDonell v. Hunter, 612 F. Supp. 1122, 1127 (S.D. Iowa 1985), aff'd as modified, 809 F.2d 1302, 1307 (8th Cir. 1987); Storms v. Coughlin, 600 F. Supp. 1214 , 1218 (S.D.N.Y. 1984). But see McDonell v. Hunter, 809 F.2d 1302, 1308 (8th Cir. 1987) ("Urinalysis properly administered is not as intrusive as a strip search or a blood test.").

145. See, e.g., Storms v. Coughlin, 600 F. Supp. 1214, 1218 S.D.N.Y. 1984) ("In a way in which having blood extracted could never be, being forced under threat of punishment to urinate into a bottle held by another is purely and simply degrading."). Accord Tucker v. Dickey, 613 F. Supp. 1124 , 1130 (D. Wis. 1985). See also Caruso v. Ward, 133 Misc. 2d 544, 547-48, 506 N.Y.S.2d 789, $792-93$ (N.Y. Sup. Ct. 1986), aff'd, 131 A.D.2d 214, 529 N.Y.S.2d 551 (N.Y. App. Div. 1987).

146. Capua v. City of Plainfield, 643 F. Supp. 1507, 1514 (D.N.J. 1986). See also Caruso v. Ward, 133 Misc. 2d 544, 548, 506 N.Y.S.2d 789, 793 (N.Y. Sup. Ct. 1986), aff'd, 131 A.D.2d 214, 520 N.Y.S.2d 551 (N.Y. App. Div. 1987). But see McDonell v. Hunter, 809 F.2d 1302, 1308 (8th Cir. 1987).

147. See Tucker v. Dickey, 613 F. Supp. 1124, $1129-30$ (D. Wis. 1985); Storms v. Coughlin, 600 F. Supp. 1214, 1220 (S.D.N.Y. 1984). But see Turner v. Fraternal Order of Police, 500 A.2d 1005,1009 (D.C. 1985) ("The intrusion of a urinalysis test requires a normal bodily function for this purpose. This is not an extreme body invasion."). 
action, the fourth amendment question is not the legitimacy of the goals themselves, but whether the goals properly may be achieved by means of drug testing. Each of the asserted governmental interests must be examined critically with this question in mind.

1. The Safety/Efficiency Interest. The governmental interest most commonly advanced in support of drug testing is to increase efficiency and safety in the workplace through detection of employees who use drugs on the job. ${ }^{148}$ Mistakes made by drug-using employees may endanger themselves or others, and under some circumstances, may result in the employer's liability. ${ }^{149}$ But while the governmental interest in efficiency and safety is an important one, the extent to which drug testing promotes this interest is limited for three reasons.

First, it is worthwhile to note that the safety/efficiency interest suggests a great deal more than testing for illegal drugs. If the efficiency of the workforce is the issue, employers should logically test for other influences that affect efficiency. Recently, Representative Patricia Schroeder argued:

[I]f [efficiency and on-the-job performance] is the reason for the [proposed urine testing], why did the Commission [on organized crime] not recommend testing for offduty use of the two most addictive and destructive drugs known to society-alcohol and tobacco? Alcoholism has ruined the careers and families of hundreds of thousands of Americans. As for smoking, the Surgeon General has documented that cigarette smoking results in greater illness and use of sick leave. If our goal is to regulate off-duty conduct which could hurt performance, alcohol and tobacco would be prime candidates. I, however, along with most Americans, would find such restrictions abhorrent. ${ }^{150}$

Second, the governmental interest in safety varies greatly with the context. The government has a significant safety interest in preventing the use of drugs by employees whose drug use would ordinarily pose situations of grave public danger, such as air traffic controllers and police officers. But this safety

148. The safety/efficiency interest has been duly noted in the cases: See, e.g., Lovvorn v. City of Chattanooga, 846 F.2d 1539, 1544 (6th Cir. 1988) (firefighters); Railway Labor Executives Ass'n v. Burnley, 839 F.2d 575, 586 (9th Cir.) (railway workers), cert. granted, 108 S. Ct. 2033 (1988); Rushton v. Nebraska Pub. Power Dist., 844 F.2d 562, 564-65 (8th Cir. 1988) (nuclear power plant employees); Jones v. McKenzie, 833 F.2d 335, 340 (D.C. Cir. 1987) (school bus attendants); National Treasury Employees Union v. Von Raab, 816 F.2d 170, 178 (5th Cir. 1987) (customs workers), cert. granted, 108 S. Ct. 1072 (1988); McDonell v. Hunter, 809 F.2d 1302, 1308 (8th Cir. 1987) (prison guards); Taylor v. O'Grady, 669 F. Supp. 1422, 1425-26 (N.D. Ill. 1987) (prison guards); Sanders v. Washington Metro. Area Transit Auth., 652 F. Supp. 765, 768-69 (D.D.C. 1986) (bus and subway drivers); Bostic v. McClendon, 650 F. Supp. 245, 250 (N.D. Ga. 1986) (police officers); Turner v. Fraternal Order of Police, 500 A.2d 1005, 1008 (D.C. 1985) (police officers); City of Palm Bay v. Bauman, 475 So. 2d 1322, 1326 (Fla. Dist. Ct. App. 1985) (police officers and firefighters).

149. See Barnard, Legal Implications of Drug Testing in the Private Sector, 2 J. L. \& Health 67, 67-69 (1987-88); Lewis, Drug Screening in the Public Sector: Municipalities and Government Workers, 2 J. L. \& HEALTH 39, 57-58 (1987-88).

150. Drug Testing Hearings, supra note 58, at 11 (statement of Representative Schroeder). See also Wisotsky, supra, note 36, at 769-70 (Given that alcohol imposes more human and economic costs on the workplace than illegal drug use, "it would take transcendental creativity to conclude that programs of testing for illegal drug use that exclude alcohol are really directed toward policing the productivity and safety of workers"). 
interest is not significant in other contexts, where danger to life does not result, as a matter of course, from the conduct of drug-using employees. ${ }^{151}$

Third, the strength of the government's safety/efficiency interest depends upon the extent to which employees now engage in drug use. If drug use is widespread, then some additional efficiency and safety might be achieved by drug testing. On the other hand, if no employees use drugs, then drug testing will not enhance efficiency or safety at all. ${ }^{152}$ The courts should not rest content with the mere assertion that a drug problem exists; given the intrusiveness of drug testing, the employer should be required to produce evidence on the extent of employee drug use to justify drug testing. ${ }^{153}$

151. See, e.g., American Fed'n of Gov't Employees v. Meese, 688 F. Supp. 547, 553 (N.D. Cal. 1988); Patchogue-Medford Congress of Teachers v. Board of Educ., 119 A.D.2d 35, 39, 505 N.Y.S.2d 888, 891 (N.Y. App. Div. 1986), aff'd, 70 N.Y.2d 57, 510 N.E.2d 325, 517 N.Y.S.2d 456 (1987).

152. This problem was presented quite strikingly by the district court in National Treasury Employees Union v. Von Raab:

That the drug testing plan is not rationally related to the achievement of a legitimate governmental interest is highlighted by the conspicuous absence of any statistics by the defendant showing any drug problem whatsoever among federal workers ... . Since Customs has not demonstrated a drug problem among its work force, the drug testing plan is an overly intrusive scheme that bears no rational relationship to the protection of an endangered governmental interest. The defendant simply has not shown that a legitimate governmental interest has been threatened.

649 F. Supp. 380, 390 (E.D. La. 1986), vacated, 816 F.2d 170 (5th Cir. 1987), cert. granted, 108 S. Ct. 1072 (1988); see also Odenheim v. Carstadt-East Rutherford Regional School Dist., 211 N.J. Super. 54, 61, 510 A.2d 709, 713 (N.J. Sup. Ct. 1985) ("The raw numbers and percentages of students referred to student assistance counseling as compared with the total student body is not reasonably related in scope to the circumstances which justified the interference, urinalysis, in the first place.").

153. Absent any evidence on the issue, one federal district court took judicial notice that "drug use among prisoners is a serious, disruptive problem within American prisons." Storms v. Coughlin, 600 F. Supp. 1214, 1220 (S.D.N.Y. 1984). This appears quite close to the limits of judicial notice. The Federal Rules of Evidence allow judicial notice of a fact only if it is "either (1) generally known within the territorial jurisdiction of the trial court or (2) capable of accurate and ready determination by resort to sources whose accuracy cannot reasonably be questioned." FED. R. Evid. 201(b). Even if drug use among prisoners is generally known or capable of accurate and ready determination, drug use among any class of employees cannot be determined as easily, and should not be the subject of judicial notice.

With more thoughtful analysis, other courts have noted the state's failure to justify drug testing with evidence of drug use among its employees. See, e.g., Taylor v. O'Grady, 669 F. Supp. 1422, 1426-30 (N.D. Ill. 1987) (detailed discussion of statistical evidence presented in support of need to test employees for illegal drug use); Amalgamated Transit Union, Local 1277 v. Sunline Transit Agency, 663 F. Supp. 1560, 1562 (C.D. Cal. 1987) ("The record does not disclose a single documented case of alcohol or drug abuse by a public employee, nor does [the state] allege such use has resulted in a bus accident."); American Fed'n of Gov't Employees v. Weinberger, 651 F. Supp. 726 (S.D. Ga. 1986) (mass drug testing of civilian police officers employed by the Army not justified without reasonable suspicion where record disclosed "no evidence whatsoever" of drug problem among officers); Penny v. Kennedy, 648 F. Supp. 815, 816 (E.D. Tenn. 1986) (mass drug testing of police officers not justified by evidence of two police officers testing positive in 1985 for illegal drug use, police chief's statement that $90 \%$ of department had no drug problem, officer's statement and "rumors" regarding switched urine samples during 1985 testing, tip from FBI that an officer had been in contact with a drug dealer, and pre-1985 statement from an officer who admitted using marijuana that "several" other officers also used marijuana), aff'd, 846 F.2d 1563 (6th Cir. 1988); Lovvorn v. City of Chattanooga, 647 F. Supp. 875, 882 (E.D. Tenn. 1986) (evidence that "several" fire fighters tested positive and "some" switched urine samples during 1985 testing, without "objective facts concerning deficient job performance or physical or mental deficiencies on the part of [the city's] fire fighters, either in general or with respect to specific personnel" did not present reasonable suspicion upon which mass testing could be based), aff'd, 846 F.2d 1539 (6th Cir. 1988); 
Without such evidence, ordering drug testing is "an act of pure bureaucratic caprice." 154

Even in those circumstances in which the employer has a strong safety and efficiency interest in identifying drug users, the question remains whether drug testing is a reasonable means of furthering that interest. As Judge Vietor explained:

There is no doubt about it-searches and seizures can yield a wealth of information useful to the searcher. (That is why King George III's men so frequently searched the colonists.) That potential, however, does not make a governmental employer's search of an employee a constitutionally reasonable one. ${ }^{155}$

Even where an employer is able to assert a strong safety/efficiency interest, drug testing is both an over- and underinclusive means of advancing that interest. Drug testing is overinclusive because the tests do not reveal whether or when the illicit substance was ingested. ${ }^{156}$ Drug testing does not indicate whether an individual was intoxicated or impaired on the job or at the time the test was given. ${ }^{157}$ It does not indicate whether an individual is drugdependent, a regular user, or likely to ingest the drug during working hours. If employers discipline an employee based upon a positive urine test, the employer in effect regulates the employee's off-duty behavior. ${ }^{158}$ In these respects, drug testing is no less overinclusive than random searches of employees' homes or wire-taps placed on employees' phones.

Capua v. City of Plainfield, 643 F. Supp. 1507, 1516 (D.N.J. 1986) ("The City of Plainfield proceeded in its urine testing campaign without any specific information or independent knowledge that any individual fire department employee was under the influence of drugs."); Patchogue-Medford Congress of Teachers v. Board of Educ., 119 A.D.2d 35, 40, 505 N.Y.S.2d 888, 891 (N.Y. App. Div. 1986) (" $[T]$ he appellants have failed to show an objective, factual basis for inferring that any one of the subject teachers uses or has used illegal drugs."), aff'd, 70 N.Y.2d 57, 510 N.E.2d 325, 517 N.Y.S.2d 456 (1987); Fraternal Order of Police v. City of Newark, 216 N.J. Super. 461, 472-73, 524 A.2d 430, 436 (N.J. Super. Ct. App. Div. 1987) ("In weighing the public need against the private intrusion, the courts are persuaded by the absence of a factual showing that drug use is widespread among the affected employees or that it presents an identifiable risk to the public."); Caruso v. Ward, 133 Misc. 2d 544, 551, 506 N.Y.S.2d 789, 795 (N.Y. Sup. Ct. 1986) (evidence that 22 police officers tested positive for drug use in force of over 26,000 could not support finding that drug use was more than "a very occasional problem at best"), aff'd, 131 A.D.2d 214, 520 N.Y.S.2d 551 (N.Y. App. Div. 1987).

154. Patchogue-Medford Congress of Teachers v. Board of Educ., 119 A.D.2d 35, 40, 505 N.Y.S.2d 888, 891 (N.Y. App. Div. 1986), aff'd, 70 N.Y.2d 57, 510 N.E.2d 325, 517 N.Y.S.2d 456 (1987). Interestingly, a representative of the President's Commission on Organized Crime, which proposed testing federal employees for illegal drug use, admitted that "[ $t]$ here is nothing to suggest that the Federal work force is a particularly suspect group in terms of drug use." Drug Testing Hearings, supra note 58, at 22 (testimony of Rodney G. Smith, Deputy Executive Director of the President's Commission on Organized Crime). In fact, after President Reagan ordered the development of drug testing programs for federal employees, officials from several federal agencies described drug use as minimal and identified alcohol as a far greater menace to alertness and productivity. Wisotsky, supra note 36, at 766. Despite the absence of empirical evidence of a drug problem among federal employees, President Reagan rejected a recommendation by the Department of Labor that a study be conducted to ascertain the extent of illegal drug use among federal workers. Id.

155. McDonell v. Hunter, 612 F. Supp. 1122, 1130 (S.D. Iowa 1985), aff'd as modified, 809 F.2d 1302 (8th Cir. 1987).

156. See supra notes $88-97$ and accompanying text.

157. Id.

158. See supra note 98 and accompanying text. 
Drug testing to detect on-the-job drug use by employees is also an underinclusive means of advancing safety and efficiency, due to its inaccuracy. Tests may be manipulated, and studies show that properly administered urine tests have very high rates of false negatives. ${ }^{159}$ Even those employees who have used drugs immediately prior to a test may not be detected.

Finally, drug testing is not only extremely overinclusive and somewhat underinclusive, but also is not the least intrusive means of furthering the governmental interest. A properly designed and implemented program of employee supervision will in many contexts lead to the detection of virtually all drug-using employees. ${ }^{160}$ Given that scientific studies are able to generate statistical and scientific evidence of the absenteeism, mistakes, and health problems caused by drug use, ${ }^{161}$ one wonders why employers do not simply take disciplinary action against those employees who make more mistakes, are 'frequently absent, or suffer from drug-related health problems? "Certainly one so under the influence of drugs as to impair the performance of his or her duties must manifest some outward symptoms . . ."162 While it is possible that an employee on drugs may escape detection for a while, risking injury to himself or another, there is certainly no guarantee that drug testing would prevent such an accident. ${ }^{163}$

Drug testing is a much more intrusive action than is necessary to serve the governmental safety/efficiency interest. To the extent that it does so, it is both over- and underinclusive. Accordingly, the governmental interest in safety and efficiency in the workplace has only a marginal nexus with drug testing.

2. The Integrity Interest. Wholly apart from the actual effects of drug use, the government's ability to do its job may be impaired if the public perceives governmental workers as drug users. Under this line of reasoning, the imposition of drug testing will comfort the public and contribute to the perception that public employees are drug-free. Because of this perception the government arguably will be able to carry out its duties more effectively.

The strength of the integrity interest, like the safety/efficiency interest discussed above, depends entirely upon context. Only in some employment

159. See supra notes $82,86 \& 99$ and accompanying text.

160. See, e.g., Taylor v. O'Grady, 669 F. Supp. 1422, 1432 (N.D. Ill. 1987) (“'trained supervision . . can detect those who chronically abuse any type of drug and who are impaired at work"); Amalgamated Transit Union, Local 1277 v. Sunline Transit Agency, 663 F. Supp. 1560, 1568 (C.D. Cal. 1987) ("the Agency only employs 50 people and this small group can be monitored by a less draconian program than that presented here").

161. See, e.g., R.T.I. STudy, supra note 13, at 8-9.

162. Capua v. City of Plainfield, 643 F. Supp. 1507, 1518 (D.N.J. 1986). A program of supervision may also be a wise alternative to drug testing from an economic standpoint. Because both EMIT screening and GC/MS confirmation are necessary to carry out a reliable drug testing program, the projected monetary cost of implementing a drug testing program in the federal workplace is staggering. It has been estimated that it will cost $\$ 265$ to $\$ 295$ million to test the entire federal workforce for illegal drug use. Drug Testing Hearings, supra note 58, at 43 (statement of Robert M. Tobias, President, National Treasury Employees Union).

163. See Lovvorn v. City of Chattanooga, 647 F. Supp. 875, 883 (E.D. Tenn. 1986), aff'd, 846 F.2d 1539 (6th Cir. 1988). 
situations is the public's perception critical to the ability of an employee to do his job effectively. The integrity interest is most commonly advanced as a justification for testing law enforcement officers. ${ }^{164}$

The argument that the perceived use of drugs by law enforcement officers will affect their ability to carry out their duties is attenuated at best. In the absence of any empirical evidence to the contrary, it is equally plausible to infer that most citizens obey law enforcement officers even if they have some vague suspicion that some officers, although not necessarily the officers they are dealing with, use illegal drugs. Furthermore, the establishment by way of testing that law enforcement officers do not use drugs can only serve to heighten respect for the officers to the extent that it is already perceived that the officers use drugs. That is, if no one thinks law enforcement officers use drugs, then confirming that they do not serves little purpose. ${ }^{165}$ Accordingly, the mere assertion of an unfavorable public perception must not suffice to trigger the government's integrity interest. To prove that drug testing is needed to preserve the integrity of law enforcement officers, the government must be required to make at least some evidentiary showing that perceived drug use actually has compromised law enforcement integrity.

Even if the public actually perceives that its law enforcement officers use illegal drugs, it is doubtful that drug testing will eliminate that perception. Although it is true that drug testing may serve to comfort the public, this comforting effect inevitably will be to some extent undermined by the report of positive test results, which will likely receive a lot of attention and strengthen the public's impression that the public employees are drug users.

The governmental interest in employee integrity does not exist in other contexts where the performance of its employees is not affected by public

164. See, e.g., Bostic v. McClendon, 650 F. Supp. 245 (N.D. Ga. 1986). The Bostic court observed:

[A] police force is entrusted with the basic duty of keeping order and protecting the public peace, an obligation which is fundamental to the preservation of society. To a considerable degree, the ability of the police force to carry out this mandate depends on the public's respect for and voluntary acquiescence to the legitimate authority of the individual officers.

Id. at 250. See also Taylor v. O'Grady, 669 F.Supp. 1422, 1425-26 (N.D. Ill. 1987) (state has "interest in maintaining the public's perception of the integrity of correctional officers as law-abiding law enforcement officials"); Feliciano v. City of Cleveland, 661 F. Supp. 578, 588 (N.D. Ohio 1987) (testing police recruits for illegal drug use' defended as necessary "to preserve the integrity of the department").

One public transportation employer also asserted that testing its employees for illegal drug use was justified in part by "the promotion of its image and the resulting increased confidence by the public." Amalgamated Transit Union, Local 1277 v. Sunline Transit Agency, 663 F. Supp. 1560, 1569 (C.D. Cal. 1987). However, characterizing the public employer's safety/efficiency interest as "paramount," id., the court did not discuss the employer's asserted integrity interest.

165. The court in Bostic v. McClendon, 650 F. Supp. 245 (N.D. Ga. 1986), apparently recognized that only well-publicized narcotics violations by police officers may impair police integrity:

There is no doubt that the open violation of narcotics law's by officers serves to seriously undermine the legitimacy of their moral authority to enforce these laws as to others, and erodes the likelihood that the public will voluntarily support and acquiesce to the authority of those officers. The open violation of narcotics laws by its officers does hinder the police department's ability to effectively carry out its statutory responsibilities, and therefore the police department does have a legitimate, if lesser, interest in preventing such off-duty conduct.

Id. at 250 (emphasis added). 
perception. ${ }^{166}$ In those areas of employment, the integrity interest should never be allowed as a justification for drug testing. ${ }^{167}$

3. Policing Drug Use. The government occasionally asserts that it should be permitted to conduct employee drug testing programs to advance its interest in eliminating the use and trade of illegal drugs. ${ }^{168}$ While it may be true, at the margin, that drug use and trade may be attacked by reducing demand for drugs through employee drug testing, the extent to which demand and trade may be reduced by drug testing is certainly speculative. ${ }^{169}$ The difficulty with this justification for drug testing is that it presents no reason to stop with public employees. ${ }^{170}$ If the elimination of drug demand is the goal, then there is no rational basis for testing only employees, let alone public employees. An equal state interest would support random drug testing at roadway blockades, election booths, street corners, and so on. Because there is no reason to believe that public employees are more likely to support the drug trade than any other citizen, random drug testing for this purpose limited to public employees as a class raises profound equal protection problems. Government cannot legitimately promote its interest in eliminating drug use and trade by testing public employees only.

166. See, e.g., American Fed'n of Gov't Employees v. Meese, 688 F. Supp. 547, 554 (N.D. Cal. 1988). Law enforcement is arguably the only area of employment in which public perception has an impact on the effectiveness of public employees.

167. See Capua v. City of Plainfield, 643 F. Supp. 1507, 1519 (D.N.J. 1986). In Capua, the court explained:

Clearly, no one can deny that the public has an interest in the integrity of its fire fighting forces.

Yet, the ability of fire fighters to perform their jobs is not dependent upon the public's "perception" of this integrity.... In other words, fire fighters can still continue to serve the public effectively, even in the face of unpopular public "perception." For the municipality of Plainfield then, it is not the demonstration of propriety that is essential but rather the determination of job-related capability.

Id. at 1519 .

168. Policing drug use is probably an implicit partial motivation for all drug testing plans, for only this concern explains the plans' failure to test for other job-impairing influences. Elimination of use and trade of illegal drugs was the primary motivation of the President's Commission on Organized Crime in recommending mass drug testing for federal employees. PRESIDENT'S COMM'N on Organized Crime, America's Habit: Drug Abuse, Drug Trafficking, and Organized Crime 483 (1986). Only recently has the federal government asserted safety and efficiency as justifications for such drug testing. See, e.g., Exec. Order No. 12,564, 3 C.F.R. 224, 226 (1987), reprinted in 5 U.S.C. $\S 7301$ app. at 32 (West Supp. 1987). Former Attorney General Edwin Meese impliedly admitted that drug testing federal employees was intended at least in part to police drug use when he explained to the United States Chamber of Commerce that "since most Americans work, the workplace can be the chokepoint for halting drug abuse." N.Y. Times, Oct. 31, 1986, § 1, at 17, col. 3.

169. After reviewing this justification for drug testing, Representative Schroeder remained wholly unconvinced: "Frankly, I think anyone who finds this logic persuasive ought to be a prime candidate for drug testing." Drug Testing Hearings, supra note 58, at 11 . Others shared Schroeder's sentiments. See, e.g., id. at 36 (statement of Kenneth T. Blaylock, National President, American Fed'n of Gov't Employees) ("after hearing Attorney General Meese's endorsement of this [drug testing] proposal, we are concerned about the potential use of hallucinogenics at the Justice Department").

170. See American Fed'n of Gov't Employees v. Meese, 688 F. Supp. 547, 554 (N.D. Cal. 1988). 


\section{E. Balancing the Competing Interests}

After examining the intrusiveness of drug testing and the countervailing state interests, courts must balance these competing values to arrive at the appropriate level of suspicion or cause required to make the testing of an individual employee reasonable under the fourth amendment. Unfortunately, courts have given rather hasty treatment to this portion of the analysis, arriving at results in a rather conclusory fashion. ${ }^{171}$ While only a few courts have allowed drug testing without any individualized suspicion, ${ }^{172}$ none have gone so far as to require probable cause. ${ }^{173}$ Most of the courts have instead held that "reasonable suspicion" is the constitutionally required standard. 174 "Reasonable suspicion" is often defined as suspicion that is based on specific objective facts and reasonable inferences that a particular employee has used drugs on the job. ${ }^{175}$ That so many courts have adopted the reasonable suspicion standard without any detailed analysis when confronted with many different factual scenarios suggests that a spirit of compromise is in the air. Though many courts oppose random testing plans, they do not want to appear to promote employee drug use by requiring probable cause. The lesser "reasonable suspicion" standard allows courts to stop random testing programs while politically saving face. Because the governmental interests in testing necessarily vary with the context, constitutional standards which reflect these factual distinctions would be more analytically satisfying. The

171. See, e.g., National Treasury Employees Union v. Von Raab, 816 F.2d 170 (5th Cir. 1987) (recites balancing test, but does not accord any weight to individual privacy interests), cert. granted, 108 S. Ct. 1072 (1988).

172. Id.; Rushton v. Nebraska Pub. Power Dist., 844 F.2d 562 (8th Cir. 1988); McDonell v. Hunter, 809 F.2d 1302 (8th Cir. 1987); Shoemaker v. Handel, 795 F.2d 1136 (3d Cir.), cert. denied, 107 S. Ct. 577 (1986); Mullholland v. Department of Army, 660 F. Supp. 1565 (E.D. Va. 1987); Storms v. Coughlin, 600 F. Supp. 1214 (S.D.N.Y. 1984).

173. One federal district court prohibited drug testing of transportation employees except upon a showing of probable cause. Jones v. McKenzie, 628 F. Supp. 1500, 1508-09 (D.D.C. 1986). The District of Columbia Circuit, however, reversed this holding on appeal. Jones v. McKenzie, $833 \mathrm{~F} .2 \mathrm{~d}$ 335 (D.C. Cir. 1987).

174. See, e.g., McDonell v. Hunter, 809 F.2d 1302 (8th Cir. 1987); Taylor v. O'Grady, 669 F. Supp. 1422 (N.D. Ill. 1987); Amalgamated Transit Union, Local 1277 v. Sunline Transit Agency, 663 F. Supp. 1560 (C.D. Cal. 1987); Feliciano v. City of Cleveland, 661 F. Supp. 578 (N.D. Ohio 1987); American Fed'n of Gov't Employees v. Weinberger, 65l F. Supp. 726 (S.D. Ga. 1986); Bostic v. McClendon, 650 F. Supp. 245 (N.D. Ga. 1986); Penny v. Kennedy, 648 F. Supp. 815 (E.D. Tenn. 1986), aff'd, 846 F.2d 1563 (6th Cir. 1988); Lovvorn v. City of Chattanooga, 647 F. Supp. 875 (E.D. Tenn. 1986), aff'd, 846 F.2d 1539 (6th Cir. 1988); Capua v. City of Plainfield, 643 F. Supp. 1507 (D.N.J. 1986); Patchogue-Medford Congress of Teachers v. Board of Educ., 70 N.Y.2d 57,510 N.E.2d 325, 517 N.Y.S.2d 456 (1987); Caruso v. Ward, 131 A.D.2d 214, 520 N.Y.S.2d 551 (N.Y. App. Div. 1987); Turner v. Fraternal Order of Police, 500 A.2d 1005 (D.C. 1985); City of Palm Bay v. Bauman, 475 So. 2 d 1322 (Fla. Dist. Ct. App. 1985).

175. See, e.g., McDonell v. Hunter, 809 F.2d 1302, 1308 (8th Cir. 1987). Reasonable suspicion is "individualized suspicion" in the sense that the particular employee's conduct makes it more likely that he: has used drugs than other employees. The reasonable suspicion standard has been criticized as contentless and devoid of specific requirements that meaningfully restrain governmental action. See, e.g., America's New Work Ethic?, supra note 80, at 908-12. The difficulty with the standard in practice is that courts may be willing to find "reasonable suspicion" if the employer is able to articulate any plausible basis for suspicion, rather than requiring the employer to demonstrate the precise objective facts and inferences necessary to support the suspicion. 
authors offer the following framework as a rough guide to achieve a more thoughtful balancing of interests.

When the governmental interest in integrity is irrelevant because the public's perception of the institution does not affect its ability to function, and when the governmental interest in safety is less important, as in situations where drug use would not inevitably present public danger, the government should not be allowed to test an employee for illegal drug use without probable cause to believe that she uses illegal drugs on the job. In such a situation, absent evidence of widespread drug use among employees, there is simply no compelling reason to alter the probable cause standard.

When the government demonstrates a strong integrity interest, by proving that (1) public perception is critical to the ability of the employees to perform their functions, and (2) there is an accurate general public perception of drug use among those employees, then the government should be allowed to test an employee based on reasonable suspicion of drug use on the job. However, courts must not accept mere assertions of unfavorable public perception. Without proof that such a perception impairs the employee's performance, drug testing is a remedy without a wrong.

Alternatively, when the government shows a strong safety interest by demonstrating that employee drug use would as a matter of course present situations of grave public danger, then the government should be permitted to test an employee based upon reasonable suspicion. As with the integrity interest, however, courts must require evidence of extensive employee drug use on the job and accurate confirmatory test procedures. Without such evidence, the government may advance its safety interest adequately by implementing a well-designed program of supervision. ${ }^{176}$

Drug testing is so intrusive, over- and underinclusive, and of such limited utility in detecting drug use on the job that testing without reasonable suspicion must not be allowed under any circumstances.

\section{F. Consent?}

Even if a testing program violates the fourth amendment, an employer could attempt to obtain employee consent to the search. In several drug testing programs challenged in the courts, employees were required to sign consent forms before testing. ${ }^{177}$

There are two reasons why these consent forms may not validate an otherwise unreasonable search. First, consent is not voluntary where each employee knows that her refusal to consent will result in disciplinary action. Second, even if employees signed the forms voluntarily, the government

176. See, e.g., Taylor v. O'Grady, 669 F. Supp. 1422, $1431-33$ (N.D. Ill. 1987).

177. See, e.g., American Fed'n of Gov't Employees v. Weinberger, 651 F. Supp. 726, 728-29 (S.D. Ga. 1987); McDonell v. Hunter, 612 F. Supp. 1122, 1126 (S.D. Iowa 1985), aff 'd as modified, 809 F.2d 1302 (8ch Cir. 1987); Caruso v. Ward, 133 Misc. 2d 544, 545-46, 506 N.Y.S.2d 789, 791 (N.Y. Sup. Ct. 1986), aff'd, 131 A.D.2d 214,520 N.Y.S.2d 551 (N.Y. App. Div. 1987). 
should never be allowed to condition public employment upon the waiver of constitutional rights.

Whether the consent of an employee is voluntary, and not the result of duress or coercion, express or implied, is a question of fact to be determined from all the circumstances. ${ }^{178}$ The critical consideration in consent form situations is what the employee reasonably believes will happen if she does not sign the form. If it is obvious under the circumstances that disciplinary action will result from a failure to sign the form, then clearly any decision to sign results from coercion. ${ }^{179}$

Regardless of the voluntariness with which consent is given, the government should not be permitted to require a waiver of fourth amendment rights as a condition of public employment. ${ }^{180}$ If government could do this, it could by the same reasoning require the relinquishment of other fundamental rights. In Frost E Frost Trucking Company v. Railroad Commission, ${ }^{181}$ the Supreme Court observed:

If the state may compel the surrender of one constitutional right as a condition of its favor, it may, in like manner, compel a surrender of all. It is inconceivable that guarantees embedded in the Constitution of the United States may thus be manipulated out of existence. ${ }^{182}$

The point is perhaps best captured by Judge Vietor in McDonell $v$. Hunter: ${ }^{183}$ "Advance consent to future unreasonable searches is not a reasonable condition of employment."'184

\section{G. The Government As Employer}

A separate but related argument that has been advanced in support of drug testing is that the government in its role as employer, as contrasted with its role as law enforcer, should be given the same latitude in dealing with its employees as any other employer in the private sector. Upon first examination this argument appears seductively simple and sound: Because private employers generally may institute employee drug testing programs, the government as employer arguably should be permitted to do the same. Upon closer analysis, however, the argument is compelling only from the government's perspective; from the employee's perspective, his fourth

178. Schneckloth v. Bustamonte, 412 U.S. 218, 248-49 (1973).

179. Lower courts confronting the issue have concluded uniformly that consent given under threat of disciplinary action is invalid because unduly coercive. See, e.g., Bostic v. McClendon, 650 F. Supp. 245, 249 (N.D. Ga. 1986); National Treasury Employees Union v. Von Raab, 649 F. Supp. 380, 387-88 (E.D. La. 1986), vacated, 816 F.2d 170 (5th Cir. 1987), cert. granted, 108 S. Ct. 1072 (1988); City of Palm Bay v. Bauman, 475 So. 2d 1322, 1324-25 (Fla. Dist. Ct. App. 1985).

180. This reasoning does not apply to a government requirement that job applicants consent to drug testing. Testing job applicants, however, only marginally protects against drug use on the job because such screening detects the use of drugs only during a brief period preceding the test. If job applicants are aware of a public employer's pre-employment testing policy, they may merely abstain from drug use for a brief period prior to screening.

181. 271 U.S. 583 (1926).

182. Id. at 594 .

183. 612 F. Supp. 1122 (S.D. Iowa 1985), aff'd as modified, 809 F.2d 1302 (8th Cir. 1987).

184. Id. at 1131 (emphasis in original). 
amendment rights may depend upon whether his employer suspects him of criminal activity. Nevertheless, several courts have adopted some form of the "government-as-employer" rationale in upholding drug testing programs. The courts' utilization of the rationale, however, has been analytically confusing; some courts view the doctrine as rendering the fourth amendment totally inapplicable to governmental searches for work-related misconduct while others view the fourth amendment as applicable to such searches, but to a lesser extent.

In Allen $v$. City of Marietta, ${ }^{185}$ for example, the court considered a fourth amendment challenge by a public employee to a drug test imposed on reasonable suspicion of drug use. The Allen court determined at the outset that the drug test was a "search" within the meaning of the fourth amendment. ${ }^{186}$ Further, the court recognized that "[g]overnment employees do not surrender their fourth amendment rights merely because they go to work for the government. They have as much of a right to be free from warrantless government searches as any other citizens."'187 Nevertheless, the court drew a distinction between governmental searches for evidence of crime and searches for noncriminal work-related misconduct. ${ }^{188}$ As to the latter type of search, the court stated: "Because the government as employer has the same rights to discover and prevent employee misconduct relevant to the employee's performance of her duties [as a private employer], the employee cannot really claim a legitimate expectation of privacy from searches of that nature."'189 Although the Allen court stated that fourth amendment protection extends to government employees, the logical result of its holding that government employees have no reasonable expectation of privacy from searches for work-related misconduct is that the fourth amendment does not protect government employees from work-related searches. This is because where there is no legitimate expectation of privacy to be free from a search, there is no fourth amendment protection. ${ }^{190}$ Accordingly, the Allen court's analysis, focusing on the government as employer's need to search, leads to the conclusion that the fourth amendment has no application at all to searches for employment-related misconduct. This holding would appear to be squarely at odds with Supreme Court precedent, particularly the Court's latest pronouncement in $O^{\prime}$ Connor $v$. Ortega ${ }^{191}$ that " [s] earches and seizures by government employers or supervisors of the private property of their employees . . . are subject to the restraints of the Fourth Amendment." 192

185. 601 F. Supp. 482 (N.D. Ga. 1985).

186. The court felt that current law mandated its determination that a drug test amounted to a fourth amendment search. Id. at 488-89.

187. Id. at 491.

188. Id.

189. Id.

190. See supra note 120.

191. 107 S. Ct. 1492 (1987).

192. Id. at 1497. 
The government-as-employer argument was stated somewhat differently in National Treasury Employees Union v. Von Raab. ${ }^{193}$ In that case, the court seemed to focus on the employee's need to be free from governmental searches: "While the fourth amendment protects against invasions for civil as well as criminal investigatory purposes, the need for protection against governmental intrusion diminishes if the investigation is neither designed to enforce criminal laws nor likely to be used to bring criminal charges against the person investigated." 194 Under the Fifth Circuit's view, the fourth amendment continues to apply to governmental searches for work-related misconduct, but in a somewhat less robust form.

At least two criticisms of this position may be made. First, it is entirely unclear why the need to be free from searches "diminishes" where the search is not intended to enforce criminal laws. It is equally plausible that a citizen's "need" to be free from a search depends upon the intrusiveness of the search itself, rather than upon whether the evidence sought is proscribed by a statute instead of an employment regulation.

Second, it is unclear why the focus of inquiry should be on the employee's "need for protection against governmental intrusion" rather than on the government's need for the intrusion. That is, the Von Raab court's proposition seems no more inherently appealing than the proposition that "the need for [the governmental intrusion itself] diminishes if the investigation is neither designed to enforce criminal laws nor likely to be used to bring criminal charges . . . "195 This is because it is difficult to classify the "need" for a search (or to be free from one) by whether the object of the search is to be used in civil or criminal proceedings. On the civil side, the government-asemployer may have a great need to discover whether an air traffic controller is impaired by alcohol, whereas it may have little need to discover that he is double parked. On the other hand, searching an employee's car for a murder weapon will be of greater necessity than a search of the car for a box of pencils taken from the office.

The civil/criminal distinction is equally unavailing when viewed from an employee's perspective. Many employees would prefer to have a search yield evidence of a minor criminal infraction than evidence causing their employment to be terminated. As this brief discussion indicates, it is of little help in determining the reasonableness of a search to focus on whether the evidence sought to be obtained relates to criminal or civil matters.

Regardless of the manner in which the government-as-employer theory is applied, however, it rests upon an extremely problematic interpretation of the fourth amendment. The doctrine makes sense, if at all, only from the perspective of the government. ${ }^{196}$ From an employee's perspective, the

193. 816 F.2d 170 (5th Cir. 1987), cert. granted, 108 S. Ct. 1072 (1988).

194. Id. at 179 (emphasis added). This reasoning was also adopted in Rushton v. Nebraska Pub. Power Dist., 844 F.2d 562, 566-67 (8th Cir. 1988).

195. Cf. Von Raab, 816 F.2d at 179.

196. Occasionally, the distinction between government as employer and as law enforcer is a hollow one, even from the government's point of view. Where evidence obtained by the government 
theory allows fourth amendment protections "to fluctuate with the 'intent' of the invading officers." 197 If an employee is subjected to a drug test because he is suspected of criminal activity, the test is illegal. But if a test is administered merely to evaluate his fitness for a job, the same urine test is legal. Clearly, this turns the fourth amendment on its head. As the Supreme Court commented in Camara v. Municipal Court, ${ }^{198}$ "It is surely anomalous to say that the individual and his private property are fully protected by the Fourth Amendment only when the individual is suspected of criminal behavior."199

This anomaly should be foreclosed by the language of the amendment itself. As Justice Brennan noted:

The Amendment states its own purpose, the protection of the privacy of the individual and of his property against the incursions of officials: the "right of the people to be secure in their persons, houses, papers, and effects." Like most of the Bill of Rights it was not designed to be a shelter for criminals, but a basic protection for everyone; to be sure, it must be upheld when asserted by criminals, in order that it may be at all effective, but it "reaches all alike, whether accused of crime or not."200

\section{H. Administrative Searches}

Several courts have upheld the drug testing of public employees under the administrative search exception to the warrant requirement. ${ }^{201}$ This exception is based upon a line of Supreme Court decisions allowing warrantless searches of commercial premises in closely regulated industries. ${ }^{202}$ In these decisions the Court has recognized significant state interests in regulating industries such as coal mining, ${ }^{203}$ firearms sales, ${ }^{204}$ junkyards, ${ }^{205}$ and the sale of alcoholic beverages. ${ }^{206}$ Because such regulation

as employer is handed over to the government's law enforcement branch for use in a criminal prosecution, the distinction between the government's roles evaporates, and employee's rights are circumvented.

197. Abel v. United States, 362 U.S. 217, 255 (1960) (Brennan, J., dissenting).

198. 387 U.S. 523 (1967).

199. Id. at 530 .

200. Abel, 362 U.S. at 254-55 (Brennan, J., dissenting) (citations omitted).

201. See, e.g., Policeman's Benevolent Ass'n v. Township of Washington, 850 F.2d 133, 141 (3d Cir. 1988); Rushton v. Nebraska Pub. Power Dist., 844 F.2d 562, 566-67 (8th Cir. 1988); National Treasury Employees Union v. Von Raab, 816 F.2d 170, 179-80 (5th Cir. 1987), cert. granted, 108 S. Ct. 1072 (1988); McDonell v. Hunter, 809 F.2d 1302, 1308 (8th Cir. 1987); Shoemaker v. Handel, 795 F.2d 1136, $1142-43$ (3d Cir.), cert. denied, 107 S. Ct. 577 (1986). But see Lovvorn v. City of Chattanooga, 846 F.2d 1539, 1545-46 (6th Cir. 1988); Penny v. Kennedy, 846 F.2d 1563 (6th Cir. 1988); Railway Labor Executive Ass'n v. Burnley, 839 F.2d 575, 585 (9th Cir.), cert. granted, 108 S. Ct. 2033 (1988); American Fed'n of Gov't Employees v. Weinberger, 651 F. Supp. 726, 734-35 (S.D. Ga. 1986); Capua v. City of Plainfield, 643 F. Supp. 1507, 1518-19 (D.N.J. 1986).

202. New York v. Burger, 107 S. Ct. 2636 (1987) (junkyards); Donovan v. Dewey, 452 U.S. 594 (1981) (coal mining); United States v. Biswell, 406 U.S. 311 (1972) (firearms); Colonnade Catering Corp. v. United States, 397 U.S. 72 (1970) (alcoholic beverages).

203. Donovan v. Dewey, 452 U.S. 594 (1981).

204. United States v. Biswell, 406 U.S. 311 (1972).

205. New York v. Burger, 107 S. Ct. 2636, 2646 (1987).

206. Colonnade Catering Corp. v. United States, 397 U.S. 72, 75, 76 (1970). The Colonnade Court held that "Congress has broad power to design such powers of inspection under liquor laws as it deems necessary to meet the evils at hand." Id. at 76. (However, the Court also held that "/ $u$ /nder the existing statutes, Congress selected a standard that does not include forcible entries without a 
tends to reduce expectations of privacy, the Court has allowed warrantless searches of commercial property where authorized by specific statutory authority. ${ }^{207}$ The Court has made it clear, however, that the exception does not excuse warrantless searches of personal property outside of the commercial context, especially warrantless searches of private homes. In Donovan v. Dewey, ${ }^{208}$ the Court explicitly distinguished searches of private residences from searches of commercial premises for purposes of the administrative search exception. ${ }^{209}$

The Court's most recent case on administrative searches, New York $v$. Burger, ${ }^{210}$ set forth three criteria which must be met in order for a warrantless search of commercial premises to be permissible. There must be a "substantial" government interest supported by the regulatory scheme permitting the search; "warrantless inspections must be "necessary to further [the] regulatory scheme;" " and "the statute's inspection program, in terms of the certainty and regularity of its application, [must] provid[e] a constitutionally adequate substitute for a warrant."211 The Court has also required a nexus between the purposes for the regulation and the interests involved in the search, ${ }^{212}$ although it did not articulate it as a formal criterion.

On its face, the administrative search exception to the warrant requirement does not apply to bodily searches of public employees. The Court has taken great pains to explicitly limit the doctrine to searches of commercial property. ${ }^{213}$ Nevertheless, several courts have extended the doctrine to apply to drug testing employees in regulated industries. ${ }^{214}$ In effect, these courts have taken a relatively narrow doctrine permitting warrantless searches of commercial property in a few historically and pervasively regulated industries and applied it to highly intrusive bodily fluid searches of individual employees who work in regulated industries. There is little that can be said about this development except that it represents a

warrant.") Id. at 77 (emphasis added). The Court's decision resulted in the return and the suppression (as evidence) of liquor seized in the warrantless search. See id. at 72, 77.)

207. See cases cited supra note 202.

208. 452 U.S. 594 (1981).

209. Id. at 598-99. The Court observed:

Our prior cases have established that the Fourth Amendment's prohibition against unreasonable searches applies to administrative inspections of private commercial property. However, unlike searches of private homes, which generally must be conducted pursuant to a warrant in order to be reasonable under the Fourth Amendment, legislative schemes authorizing warrantless administrative searches of commercial property do not necessarily violate the Fourth Amendment. The greater latitude to conduct warrantless inspections of commercial property reflects the fact that the expectation of privacy that the owner of commercial property enjoys in such property differs significantly from the sanctity accorded an individual's home ....

Id. (citations and footnote omitted); see also New York v. Burger, 107 S. Ct. 2636, 2642 (1987).

210. 107 S. Ct. 2636 (1987).

211. Id. at 2644 (quoting Donovan v. Dewey, 452 U.S. 594, 600 (1981)).

212. Id. at 2643 ("I $[$ ]he [administrative search] doctrine is essentially defined by 'the pervasiveness and regularity of the federal regulation' and the effect of such regulation upon an owner's expectation of privacy.") (emphasis added).

213. See supra note 209.

214. See cases cited supra note 201. 
radical departure from precedent. ${ }^{215}$ The Sixth Circuit has noted this point quite forcefully:

To allow widespread mandatory drug testing of individuals by analogizing it to the relaxed standards governing the less intrusive searches of places allowed under the administrative search warrant exception fundamentally misapprehends that doctrine.

Given the origins of the administrative search warrant exception, it seems incredible that the argument in favor of mandatory drug testing should be based on this doctrine. ${ }^{216}$

The application of the administrative search doctrine to bodily searches is particularly unfortunate in view of the relaxation of the doctrine itself in Burger. There, the Court found a "substantial" state interest in the regulation of junkyards. ${ }^{217}$ Warrantless searches were considered necessary to further the regulatory scheme because a warrant requirement might impair the "surprise" found crucial to the Court in order to enforce the regulatory scheme. ${ }^{218}$ Finally, the Court found that the regulatory scheme provided a "constitutionally adequate substitute for a warrant."219 As Justice Brennan noted in his dissent, however, the only real restriction on the searches was that they must occur during the business hours of junkyards. ${ }^{220}$ That the

215. Perhaps the most egregious of these cases is Shoemaker v. Handel, 795 F.2d 1136, 1142-43 (3d Cir.), cert. denied, 107 S. Ct. 577 (1986). In that case, the Third Circuit applied the administrative search exception to uphold random warrantless drug testing of race horse jockeys in New Jersey. The court found that the regulatory scheme including the drug testing served two strong state interests: "protection of the wagering public," id. at 1142 , and "protection of the wagering public's confidence in the integrity of the industry," id. Moreover, the court found that the pervasive regulation of the horse racing industry reduced jockeys' justifiable privacy expectations. Id. The court reached this conclusion by observing that "[e]ven before the [drug testing] regulations challenged here were adopted, the jockeys were aware that the Commission had promulgated regulations providing for warrantless searches of stables." Id.

Aside from the fact that Shoemaker extended the administrative search exception to searches of individuals, several criticisms of the case may be made. First, the court failed to inquire whether there was any nexus between the regulation in the industry and the privacy expectations of those to be searched. Although the jockeys were on notice that warrantless searches of stables might occur to prevent the use of drugs in the horses, none of the regulations prior to the drug testing suggested that the jockeys' persons might be subject to search. The jockeys' expectations of privacy in the act of urination were in no way reduced by any of the regulations in the industry.

Second, it is questionable whether the interests at stake in Shoemaker were sufficiently weighty to warrant the drug testing regulations. There was no evidence that the horse racing industry's public image was tainted by perceived drug use among jockeys; the court simply accepted the state's asserted need for testing to ensure the industry's integrity. There was similarly no evidence of what effect, if any, the use of drugs by the jockeys might have had.

Since Shoemaker, it has become commonplace for a public employer to defend a challenged drug testing program with the argument that its need for drug-free employees is at least as great as the New Jersey Racing Commission's need for drug-free jockeys. See, e.g., McDonell v. Hunter, 809 F.2d 1302, 1308 (8th Cir. 1987); Rushton v. Nebraska Pub. Power Dist., 653 F. Supp. 1510, 1524 (D. Neb. 1987), aff'd, 844 F.2d 562 (8th Cir. 1988); American Fed'n of Gov't Employees v. Weinberger, 651 F. Supp. 726, 734 (S.D. Ga. 1987); National Ass'n of Air Traffic Specialists v. Dole, No. A87-073, slip op. (D. Alaska Mar. 27, 1987). The ease with which this argument may be advanced in support of virtually any challenged testing program suggests that the Shoemaker court failed to analyze New Jersey's asserted interests critically.

216. Lovvorn v. City of Chattanooga, 846 F.2d 1539, 1545-46 (6th Cir. 1988).

217. $107 \mathrm{~S}$. Ct. at 2646 .

218. Id. at $2647-48$.

219. Id. at 2648 .

220. Id. at 2655 (Brennan, J., dissenting). 
search actually conducted was unrelated to the administrative regulations that initially justified the search, but rather was aimed at criminal law enforcement, was not viewed as a sufficient difficulty to remove the search from the administrative search exception. ${ }^{221}$

In the wake of Burger, it becomes clear that almost any regulatory scheme may validly authorize a warrantless search as long as the legislature is able to articulate some plausible significant interest and at least one restriction on the time, place, and scope of the authorized searches. Moreover, the search will not be objectionable merely because its sole purpose is criminal law enforcement. As Justice Brennan observed, “[t]he implications of the Court's opinion, if realized, will virtually eliminate Fourth Amendment protection of commercial entities in the context of administrative searches."222 Applying the administrative search doctrine to bodily searches of individual employees will have the further effect of virtually eliminating fourth amendment protection of individuals employed in commercial entities. The implications of this result may be to allow a legislature to effectively abrogate much of traditional fourth amendment protection by regulatory fiat.

\section{The Supreme Court Docket: Von Raab and Burnley-Cert. Granted}

The Supreme Court has recently granted certiorari on two drug testing cases in which the Fifth and Ninth Circuits reached dramatically different conclusions. These cases merit individual treatment because they will frame the issues for the Court's first look at the fourth amendment implications of drug testing public employees.

1. National Treasury Employees Union v. Von Raab. In Von Raab, the National Treasury Employees Union brought suit against the Commissioner of the United States Customs Service on behalf of Customs Service employees to enjoin the implementation of a drug testing program. The Customs Service is primarily engaged in enforcing import, customs, and related laws, including the interdiction of narcotics smuggling. ${ }^{223}$ The drug testing program involved is somewhat unusual in that it applies only to those employees who apply for and are selected for promotion to certain covered positions. ${ }^{224}$ Those employees who are selected for promotion are given at least five days' notice of the date on which they will be required to submit a urine sample. ${ }^{225}$ The urine specimens are collected under supervision, but not direct observation. ${ }^{226}$ The specimens are first tested by EMIT, then any positive results are confirmed by a GC/MS test. ${ }^{227}$ Those employees who refuse to

221. Id.

222. Id. at 2657 (Brennan, J., dissenting).

223. 816 F.2d 170, 173 (5th Cir. 1987).

224. Id.

225. Id.

226. Id. at 174 .

227. Id. If the EMIT and GC/MS tests prove positive, the employee may designate an independent laboratory also to test the specimen. Id. 
submit to the test forfeit their right to promotion, ${ }^{228}$ and those who test positive are subject to dismissal. ${ }^{229}$

The Customs Service justified the program by reference to the role of the Service in narcotics interdiction and the possibility that illegal drug use by Service employees would "undermine[] . . . the integrity of the Service."23o Perhaps most significantly, as the Fifth Circuit noted,

[t]he Customs Service did not attempt to justify drug screening on the ground that it suspected a significant level of drug use among its employees. Indeed, the Commissioner has described the Service as "largely drug free," and, in five months of testing, none of the tests of current employees seeking a job change was positive. Even among applicants not already employed, only one person's test was positive. ${ }^{231}$

The district court enjoined the drug testing plan, finding it "utterly repugnant to the United States Constitution" for a variety of reasons. ${ }^{232}$ The Court of Appeals for the Fifth Circuit reversed, concluding that the drug testing plan was constitutional. ${ }^{233}$ Although the court found that the drug tests were searches within the meaning of the fourth amendment, ${ }^{234}$ the court concluded that the searches were reasonable in view of the governmental interests at stake. ${ }^{235}$ The court was not bothered by the absence of any evidence of drug use among Customs Service employees. In its view, "[i]t is not unreasonable to set traps to keep foxes from entering hen houses even in the absence of evidence of prior vulpine intrusion or individualized suspicion that a particular fox has an appetite for chickens." 236 The court also found support for its conclusion by reference to the government's role as an employer, ${ }^{237}$ the fact that only those who apply for a promotion are subject to testing, ${ }^{238}$ the noncriminal nature of the search, ${ }^{239}$ and the case law permitting administrative searches of closely regulated industries. ${ }^{240}$

228. Id. at 173 .

229. Neal, Mandatory Drug Testing, 74 A.B.A.J. 58, 60 (Oct. 1988).

230. Von Raab, 816 F.2d 170, 173 (5th Cir. 1987).

231. Id.

232. 649 F. Supp. 380, 391 (E.D. La. 1986). The district court found that the drug testing program violated the fourth amendment, the self-incrimination clause of the fifth amendment, penumbral privacy rights, as well as due process of law.

233. Von Raab, 816 F.2d 170 (5th Cir. 1987).

234. Id. at 175-76. In this context, the court noted that "[t]here are few activities in our society more personal or private than the passing of urine." Id.

235. Id. at 176-80. Although the court began its analysis of the reasonableness of the drug test searches by reciting the Bell $v$. Wolfsh balancing test, see supra note 110 , it is questionable whether the court in fact applied it. Rather than balancing the governmental interests against the individual interests at stake, the court appears to have simply listed the governmental interests and then found them compelling. As one court noted, "[i]t is not surprising, given that the court can identify only factors favoring testing, that it concludes that testing is constitutionally permissible as a reasonable search." Feliciano y. City of Cleveland, 661 F. Supp. 578, 592 (N.D. Ohio 1987).

236. Von Raab, 816 F.2d at 179 . The notion that chickens are to foxes what drugs are to Customs Service employees seems belied by the uncontroverted evidence that even before drug testing the Customs employees were largely drug free.

237. Id. at 178-79; see supra notes $185-200$ and accompanying text.

238. Von Raab, 816 F.2d at 178.

239. Id. at 179; see supra notes $193-200$ and accompanying text.

240. Von Raab, 816 F.2d at 179-80; see supra notes 201-22 and accompanying text. 
2. Railway Labor Executives Association v. Burnley. In Burnley, the Railway Labor Executives Association brought suit to enjoin the implementation of a drug and alcohol testing program promulgated by the Federal Railroad Administration (FRA) as violative of the fourth amendment. ${ }^{241}$ The FRA initiated the program in 1985 through regulations requiring all members of a railroad crew to be tested after any major train accident, impact accident, or fatal accident involving the crew. ${ }^{242}$ The regulations also authorize the railroads to test employees for "cause." 243

FRA defended the program by producing evidence of drug and alcoholrelated accidents during a nine year period preceding the initiation of the program. ${ }^{244}$ FRA also submitted evidence of the dangers involved in railroad transport of hazardous materials. ${ }^{245}$ The district court found the program satisfactory under the fourth amendment and granted summary judgment in favor of FRA. ${ }^{246}$

On appeal, the Ninth Circuit Court of Appeals reversed, holding that the portions of the program permitting drug testing in the absence of reasonable suspicion violated the fourth amendment. ${ }^{247}$ The court first held that the drug tests were searches under the fourth amendment, but that a warrant would not be required. ${ }^{248}$ Next, the court declined FRA's invitation to apply the administrative search doctrine to the drug testing program. ${ }^{249}$ Balancing

241. 839 F.2d 575 (9th Cir. 1988). The Railway Labor Executives Association also asserted several statutory grounds for injunctive relief that are not relevant to the fourth amendment issues in the case.

242. Major train accidents are defined as those involving a fatality, release of hazardous material with either evacuation or reportable injury, or $\$ 500,000$ damage to railroad property. Impact accidents include those involving a reportable injury or $\$ 50,000$ damage to railroad property. 49 C.F.R. $\$ 219.201$ (1987).

243. 49 C.F.R. $\$ 219.301-.309$ (1987). Cause can be established in three different ways: by reasonable suspicion, by an accident, or by a violation of certain operating rules. Reasonable suspicion that constitutes cause for a urine test is established when at least two supervisors have an articulable suspicion that an employee is currently under the influence of or impaired by alcohol or drugs based on the supervisor's personal observation of the employee's appearance, behavior, speech, or body odors. 49 C.F.R. $\$ 219.301$ (c)(2) (1987). One of the two supervisors possessing articulable suspicion must have received at least three hours of training in detecting drug intoxication.

244. Bumley, 839 F.2d at 579.

245. Id.

246. Id. at 577 .

247. Id. at 588-89.

248. Id. at $582-83$.

249. Id. at 584-85. See supra notes 201-22 and accompanying text. Specifically, the court noted that "[a]ll of the decisions in this line of cases have upheld warrantless searches of property, not of persons, and we decline to make such an extension in this case." Burnley, $839 \mathrm{~F} .2 \mathrm{~d}$ at 584 . Later in the court's opinion, however, it waffled somewhat on this point. After noting that the administrative search exception was particularly inapplicable to this case because the regulation in the industry had not reduced the employees' expectations of privacy in their urine, the court wrote: "Thus we conclude that the administrative inspection standard, which allows warrantless searches of the premises of pervasively regulated industries, is not applicable to searches of persons even when they are employed in those industries, unless the employees are the principal concern of the industry regulation." Id. at 585 (emphasis added). Thus, there is some ambiguity in the opinion about how the court would view a case in which the employees were the principal concern of the regulations, such as a drug testing program involving police officers. Cf. Policeman's Benevolent Ass'n of New Jersey v. 
the governmental and individual interests involved, the court concluded that testing in the absence of reasonable suspicion was unreasonable. ${ }^{250}$

\section{Von Raab and Burnley in the Supreme Court. Although at the court of} appeals level drug testing was upheld in Von Raab and struck down in Burnley, Von Raab presents a much weaker case. In Von Raab, the only governmental interest assertedly supported by the drug testing program is the integrity of the Customs Service employees. ${ }^{251}$ The uncontroverted evidence in the record, however, is that the Customs Service employees are largely drug free. ${ }^{252}$ There is also no evidence in the record that the integrity of the Customs Service has been called into question by any public perception of drug use among its employees. As a result, the extent to which drug testing will further the governmental interests involved is surely minimal.253 The nexus between the tests and the government's integrity interest is further attenuated by the fact that nearly all of those employees who do use illegal drugs will go undetected by the tests because the employees are given at least five days' notice of the testing date. ${ }^{254}$ As a result, there is little if any connection between the drug testing program and the asserted justifications for it; the program is pointless and unnecessary. The only helpful aspect of the program in Von Raab is that only those who apply for a promotion to certain positions are subject to the tests. ${ }^{255}$ The program thus has a flavor of voluntariness lacking in programs which randomly test the entire workforce. This factor cannot justify an otherwise impermissible drug testing program, however, because it would permit the government to attach an unconstitutional condition to the Customs Service employees' ability to seek promotion. ${ }^{256}$ This aspect of the case also highlights in a rather ironic way the

Township of Washington, 850 F.2d 133 (3d Cir. 1988) (drug testing of police officers permissible under administrative search doctrine).

250. Burnley, 839 F.2d at 588-89. The court framed its inquiry into the reasonableness of the search in terms of the two pronged test articulated by the Supreme Court in O'Connor v. Ortega: (1) whether the search was justified at its inception, and (2) whether the search was reasonably related in scope to the justifications for the search. Id. at 587; see supra notes 113-17 and accompanying text. The court then concluded that drug testing was "justified at its inception" only where there is individualized suspicion of drug use. $839 \mathrm{~F} .2 \mathrm{~d}$ at 587 . The court reached this conclusion, however, only after noting that the drug tests involved searches of persons, id, and the privacy interests implicated by the tests were more than minimal, id. at 588 . Thus, as noted supra note 116 and accompanying text, the "justified at its inception" test was applied only by simultaneously considering the scope and intrusiveness of the search. The case is therefore an example of the lack of utility of the $O$ "Connor "justified at its inception" standard. In the end, a search is "justified at its inception" when it is "justified," and whether a search is "justified" or not is a question that can only be answered by balancing the competing interests at stake.

251. See supra note $\mathbf{2 3 0}$ and accompanying text.

252. See supra note 231 and accompanying text.

253. See generally supra notes 164-67 and accompanying text.

254. The only drugs detectable more than five days after their use are some types of barbiturates, extremely powerful doses of methaqualone, and cannaboids (marijuana) in the body of a chronic user. See supra note 97 and accompanying text. Although it is possible that some employees will be so addicted to drugs that they will be unable to abstain for five days, many of these employees may be detectable by physical observation.

255. See supra note 224 and accompanying text.

256. See supra notes $180-84$ and accompanying text. 
pointlessness of drug testing employees in general: here, only those employees selected for promotion, those who by definition have proven themselves to be outstanding employees, are subjected to drug testing. Von Raab should be reversed.

In contrast to Von Raab, the drug testing program at issue in Burmley is more directly supported by the significant state interest of safety and efficiency among railroad employees. There is at least some evidence in the record of drug use among employees, and of prior drug-related accidents. The evidence does not reveal, however, the extent of drug use among the employees. Furthermore, the program does not appear to tailor the drug test to those employees whose use of drugs would cause the danger to be prevented. Nevertheless, the Court should probably affirm the decision in Burnley because the governmental interests at stake are significant, and could be furthered by drug tests based upon reasonable suspicion without unduly intruding upon the privacy rights of employees.

\section{IV}

\section{Drug Testing and Procedural Due Process}

In addition to the fourth amendment issues discussed above, drug testing may under some circumstances be limited by procedural due process concerns. Section one of the fourteenth amendment provides in relevant part that no state shall "deprive any person of life, liberty or property without due process of law." 257 The fifth amendment similarly restrains the federal government. ${ }^{258}$ The due process clause protects against arbitrary deprivation of both property and liberty interests. ${ }^{259}$

\section{A. Protected Property Interests}

Since the early 1970's, the Supreme Court has recognized that public employees who have protected property interests in continued government employment may not be terminated without due process of law. ${ }^{260}$ For a public employee to claim a property interest protected by the due process clause, he must show a legitimate claim of entitlement to continued employment. ${ }^{261}$ In one way or another, these entitlements ensure that termination decisions are made only for some form of cause. Such claims of entitlement are "not created by the Constitution, "they are created and their dimensions are defined by existing rules or understandings that stem from an independent source such as state law." "'262

257. U.S. Const. amend. XIV, § 1.

258. See id. at V, cl. 3.

259. Wells v. Doland, 711 F.2d 670, 675 (5th Cir. 1983).

260. See, e.g., Board of Regents v. Roth, 408 U.S. 564 (1972); Perry v. Sindermann, 408 U.S. 593 (1972).

261. Board of Regents v. Roth, 408 U.S. 564, 577 (1972).

262. Cleveland Bd. of Educ. v. Loudermill, 470 U.S. 532, 538 (1985) (quoting Board of Regents v. Roth, 408 U.S. 564,577 (1972)). Due process protects only current public employees, not applicants for positions. See Roth, 408 U.S. at 576-77; Anderson v. City of Philadelphia, 845 F.2d 
Under this rationale, the Supreme Court has found statutes, ${ }^{263}$ informal practices or customs, ${ }^{264}$ and statements in employee handbooks ${ }^{265}$ sufficient to create property interests in continued public employment. Every court examining this issue in drug testing cases has found that public employees possess protected property interests in continued government employment. 266

When an independent rule or understanding confers upon a public employee a property interest in continued government employment, he may not be terminated without due process. ${ }^{267}$ The second step in due process analysis requires one to determine the process that is due the employee. ${ }^{268} \mathrm{~A}$ legislature may decide not to confer a property interest in public employment at all, but once it does, it may not authorize deprivation of that property interest without proper procedural safeguards. ${ }^{269}$

Determining the procedural safeguards required to meet the due process clause is a federal constitutional issue resolved by the courts. ${ }^{270}$ In Cleveland Board of Education v. Loudermill, the Supreme Court explicitly held that public employees with property interests in continued employment have a due process right to some type of pre- or post-termination hearing. ${ }^{271}$ The Court held that due process requires that the employee be provided "oral or written notice of the charges against him, an explanation of the employer's evidence, and an opportunity to present his side of the story," usually at a pretermination hearing. ${ }^{272}$ The pre-termination hearing need not be elaborate, but it should determine "whether there are reasonable grounds to believe that the charges against the employee are true and support the proposed action.",273

Thus, before government may terminate a public employee based upon a positive drug test result, it must at a minimum provide the employee with notice of the charges against him, an explanation of the evidence, and an opportunity to contest the evidence at a pre-termination hearing. Because

1216, 1220-21 (3d Cir. 1988) (applicants for city police and prison officer positions do not have legitimate claims of entitlement to employment which invoke the protections of the due process clause); see also Comment, Entitlement, Enjoyment, and Due Process of Law, 1974 DukE L.J. 89, 101-02.

263. Cleveland Bd. of Educ. v. Loudermill, 470 U.S. 532, 539 (1985).

264. Perry v. Sindermann, 408 U.S. 593, $602-03$ (1972).

265. Allen v. City of Marietta, 601 F. Supp. 482, 492 (N.D. Ga. 1985).

266. See infra notes 276-77.

267. Cleveland Bd. of Educ. v. Loudermill, 470 U.S. 532, 541 (1985).

268. Id. at 541 .

269. Id. (quoting Arnett v. Kennedy, 416 U.S. 134, 167 (1974)).

270. See, e.g., Cleveland Bd. of Educ. v. Loudermill, 470 U.S. 532, $541-42$.

271. Id. at 542 and n.7.

272. Id. at 546. The Court described "' 'the root requirement' of the Due Process Clause as being 'that an individual be given an opportunity for a hearing before he is deprived of any significant property interest.' "Id. at 542 (quoting Boddie v. Connecticut, 401 U.S. 371,379 (1971)) (emphasis in Boddie). Although due process ordinarily requires a pre-termination hearing, in certain limited cases a post-deprivation hearing will suffice. Id. at 542 n.7. See Ewing v. Mytinger \& Casselberry, Inc., 339 U.S. 594 (1950).

273. Id. at 545-46. 
some drug tests may be quite inaccurate, ${ }^{274}$ it is especially important that employees be afforded a meaningful opportunity to challenge positive test results prior to termination. ${ }^{275}$

Several courts have considered whether terminations or other adverse disciplinary actions pursuant to positive test results have accorded employees sufficient procedural due process. Some have held that adequate due process was given, ${ }^{276}$ while others have held that testing programs followed by subsequent disciplinary actions violated due process. ${ }^{277}$ In light of the clearer and enhanced procedural due process rights accorded public employees in Loudermill, ${ }^{278}$ due process challenges to terminations based upon positive drug test results may meet with greater success in the future.

\section{B. Protected Liberty Interests}

In addition to property interests in continued government employment, public employees have constitutionally protected liberty interests in their reputation and good name. The Supreme Court has rejected the claim "that reputation alone, apart from some more tangible interests such as employment, is either 'liberty' or 'property' by itself sufficient to invoke the procedural protection of the Due Process clause." 279 However, an injury to reputation that occurs when government alters a more tangible interest such as an interest in employment ${ }^{280}$ or a legal right or status ${ }^{281}$ clearly implicates "liberty" and requires due process.

274. See supra notes 70-104 and accompanying text.

275. See, e.g., Capua v. City of Plainfield, 643 F. Supp. 1507, 1521 (D.N.J. 1986).

276. See, e.g., Bostic v. McClendon, 650 F. Supp. 245, 251 (N.D. Ga. 1986); Lovvorn v. City of Chattanooga, 647 F. Supp. 875, 883 (E.D. Tenn. 1986), aff'd, 846 F.2d 1539 (6th Cir. 1988); Shoemaker v. Handel, 619 F. Supp. 1089 , 1105 (D.N.J. 1985), aff'd, 795 F.2d 1136 (3d Cir.) (issue not argued on appeal), cert. denied, 107 S. Ct. 577 (1986); Allen v. City of Marietta, 601 F. Supp. 482, 494 (N.D. Ga. 1985). It must be noted that Allen was decided prior to the Supreme Court's decision in Cleveland Bd. of Educ. v. Loudermill, 470 U.S. 532 (1985). In Allen, public employees with property interests in continued employment were dismissed without a pre-termination hearing for suspected illegal drug use. 601 F. Supp. at 492. Nevertheless, the court held that the dismissals comported with due process because a city ordinance provided that employees could be dismissed immediately for certain conduct threatening health or safety, Id. at 493. In light of Loudermill, this decision is probably erroneous. Loudermill establishes that simply because the government creates a property interest in continued employment does not mean that it can also define the requisite due process to be accorded that interest. 470 U.S. at 541 . The U.S. Constitution defines the process that is due and the Loudermill court firmly rejected the "bitter with the sweet approach [as] misconceiv[ing] the constitutional guarantee .... The right to due process is conferred, not by legislative grace, but by constitutional guarantee." "Id. (quoting Arnett v. Kennedy, 416 U.S. 134, 167 (1974)). See Bible, supra note 78, at 342-47.

277. See, e.g., Everett v. Napper, 833 F.2d 1507, 1512 (11th Cir. 1987) (even though plaintiff received notice and an adequate pre-termination hearing, violation of due process occurred because he was suspended without pay); National Treasury Employees Union v. Von Raab, 649 F. Supp. 380 , 390 (E.D. La. 1986) (drug testing plan so unreliable as to violate due process), vacated, 816 F.2d 170 (5th Cir. 1987), cert. granled, 108 S. Ct. 1072 (1988); Capua v. City of Plainfield, 643 F. Supp. 1507, 1521 -22 (D.N.J. 1986); Jones v. McKenzie, 628 F.Supp. 1500, 1504-07 (D.D.C. 1986) (denial of procedural due process particularly egregious because plaintiff terminated without hearing on basis of two unconfirmed EMIT tests), rev d in part on other grounds, 833 F.2d 335 (D.C. Cir. 1987).

278. 470 U.S. 532 (1985).

279. Paul v. Davis, 424 U.S. 693, 701 (1976).

280. Id. at 709-10. 
The liberty protected by the due process clause encompasses an individual's freedom to work and earn a living, ${ }^{282}$ and an individual may have constitutionally protected liberty interests even if she does not have a property interest in continued employment. ${ }^{283}$ A public employer implicates an employee's due process liberty interests when, in discharging her, the employer makes charges which stigmatize or seriously damage the standing of the employee in the community, making it difficult for her to take advantage of other employment opportunities. ${ }^{284}$

In order to prove a deprivation of constitutionally protected liberty interests without due process of law, public employees dismissed for positive drug test results must show that (1) they were stigmatized by the discharge process; ${ }^{285}(2)$ the test results were false; ${ }^{286}(3)$ the grounds for dismissal were made public or were readily available to prospective employers; ${ }^{287}$ and (4) the employees were denied a meaningful hearing to contest the charges and to clear their names. ${ }^{288}$

Public employees discharged for positive drug test results have claimed an unfair deprivation of protected liberty interests in several instances. ${ }^{289}$ It is likely that discharge for drug use will severely hinder an employee's opportunities to obtain a job elsewhere. Given the potentially low accuracy rates of the tests, the reasons for the discharge will occasionally be false. If a potential employer does not already know of local drug-related discharges, applicants for employment will often be required to describe their previous employment and reasons for leaving, thus publicizing the information.

281. Wisconsin v. Constantineau, 400 U.S. 433, 436-37 (1971) (without a prior hearing, city official may not publicly list a person as an alcoholic because of danger of unfair stigmatization and infringement of legal right to buy liquor).

282. Wells v. Doland, 711 F.2d 670,676 (5th Cir. 1983).

283. Id. at 675-76. Consequently, even though applicants for employment do not have constitutionally protected property interests in that employment, they do possess liberty interests in their reputation and freedom to work. These interests may be violated if they are denied employment in a way which stigmatizes them and impairs their ability to obtain a job elsewhere in the community. See Anderson v. City of Philadelphia, 845 F.2d 1216, 1221 -22 (3d Cir. 1988) (applicants allowed to raise liberty claims but claims rejected because no showing that city publicized stigmatizing polygraph test results).

284. Wells v. Doland, 711 F.2d 670, 676 (5th Cir. 1983).

285. Id.

286. Codd v. Velger, 429 U.S. 624, 627-28 (1977) (per curiam) (plaintiff not entitled to hearing because he did nol claim distributed information was false); Blanton v. Griel Memorial Psychiatric Hosp., 758 F.2d 1540, 1544 (11th Cir. 1985) (no violation of plaintiff's liberty interests where he failed to allege or show that employer's charges were false).

287. Jones v. McKenzie, 628 F. Supp. 1500, 1505 (D.D.C. 1986) ("While there is no evidence that defendants published their drug abuse finding, it is a reasonable inference that, unless expunged, the rationale for her termination will remain in her file for automatic publication to any prospective employer of plaintiff."), rev'd in part on other grounds, 833 F.2d 335 (D.C. Cir. 1987). See Cleveland Bd. of Educ. v. Loudermill, 470 U.S. 532, 547 n.13 (1985) (plaintiff's failure to allege that reasons for dismissal were publicized justified dismissal of due process liberty claim).

288. In re Selcraig, 705 F.2d 789, 795-96 (5th Cir. 1983).

289. See, e.g., Bostic v. McClendon, 650 F. Supp. 295, $251-52$ (N.D. Ga. 1986) (no violation of protected liberty interests because plaintiffs did not allege or prove that dismissal charges were false); Capua v. City of Plainfield, 643 F. Supp. 1507, 1520-21 (D.N.J. 1986) (due process liberty interests violated); Jones v. McKenzie, 628 F. Supp. 1500, 1505 (D.D.C. 1986), rev'd in part on other grounds, 833 F.2d 335 (D.C. Cir. 1987) (plaintiff established elements of due process liberty claim). 
Finally, several testing programs have not provided an adequate opportunity to be heard before discharging the accused employees. ${ }^{290}$ Under some circumstances, therefore, due process may provide public employees protection against unjust discharge based on drug testing. ${ }^{291}$

\section{Conclusion}

Fourth amendment analysis is, in essence, a framework for evaluating social policy in difficult areas in which the interests of society and individuals clash. Expectations of privacy must be "legitimate," and competing societal and individual interests must be "balanced" in order to determine what is "reasonable." As a forum for resolving these issues, the development of fourth amendment doctrine represents a chronicle of societal tolerance, of the degree of latitute individuals will be given and the breadth of power the state will be allowed to exercise on behalf of society.

If upheld, drug testing will represent an unfortunate chapter in the fourth amendment chronicle, a chapter in which individual interests were subordinated to societal interests to a previously unheard of extent with insufficient justification. As a highly intrusive bodily search without any individualized suspicion, drug testing sets a precedent for the government to monitor the bodily fluids of its subjects in order to supervise their activities. Such a reduction of the rights of individuals should not be permitted without a more exacting scrutiny than drug testing can withstand.

[The Bill of Rights] guarantee[s] to us all the rights to personal and spiritual selffulfillment. But the guarantee is not self-executing. As nightfall does not come at once, neither does oppression. In both instances, there is a twilight when everything remains

290. See, e.g., Capua v. City of Plainfield, 643 F. Supp. 1507, 1520-21 (D.N.J. 1986).

291. Several other constitutional challenges have been made against drug testing programs. At least two employees discharged for positive urinalysis tests have claimed a violation of their right to the equal protection of the laws, but these claims have been rejected by the courts. See Shoemaker v. Handel, 795 F.2d 1136, $1143-44$ (3d Cir.), cert. denied, 479 U.S. 577 (1986); Everett v. Napper, 833 F.2d 1507, 1513-14 (11th Cir. 1987). Any claim based on the over-or underinclusiveness of a drug testing program is likely to be rejected on the basis that the government can justifiably implement testing one step at a time. See Shoemaker, 795 F.2d at 1143-44; Williamson v. Lee Optical, 348 U.S. 483,489 (1955).

A novel challenge to one drug testing program was made in Rushton v. Nebraska Pub. Power Dist., 844 F.2d 562 (8th Cir. 1988). In that case, two employees challenged the policy statement accompanying a nuclear power plant's drug testing plan which contained the statement that drug and alcohol abuse was an illness. The plaintiffs alleged that the statement violated their right to the free exercise of their religion because they believed that drug and alcohol abuse was a sin, not an illness, and their participation in the program gave their implied approval of the heretical policy statement. $I d$. at 564. Applying Supreme Court precedent, the Eighth Circuit asked whether the regulation burdened, directly or indirectly, the plaintiffs' religious practice. Finding that it did, the court found that the limitation on their religious practice was justified by the overriding governmental interest of preserving safety at the nuclear power plant. The court further found that the mandatory testing of all designated employees was the least restrictive means of achieving its objective. The court denied the plaintiffs an exemption from the program because of the uncertainty that background checks and affidavits submitted by the burdened employees would truly insure that they were drug free. $I d$. at 565-66. 
seemingly unchanged. And it is in such twilight that we all must be most aware of change in the air-however slight-lest we become unwitting victims of the darkness. ${ }^{292}$

292. W. Douglas, The Douglas Letters 162 (M. Urofsky ed. 1987) (Sept. 10, 1976, letter to Young Lawyers Section of the Wash. State Bar Ass'n). 
